\title{
Entrepreneurial learning from failure: An interpretative phenomenological analysis
}

\author{
Jason Cope \\ The Hunter Centre for Entrepreneurship \\ University of Strathclyde \\ Room 14.09 \\ Livingstone Tower \\ 26 Richmond Street \\ Glasgow \\ G1 1XH.
}

Tel: $0044(0) 1415484847$

Fax: $0044(0) 1415527602$

Email: jason.cope@strath.ac.uk

\begin{abstract}
This paper develops a deeper conceptualisation of venture failure from a learning perspective. Moving beyond the causes of failure, I seek to develop a richer picture of the impact and outcomes of failure and the learning processes by which entrepreneurs actively grieve for, and recover from, the loss of a business. Based on interpretative phenomenological research with eight entrepreneurs, this paper adds valuable empirical weight to extant conceptual discussions of failure. Marrying emergent literature on entrepreneurial learning with theories of failure, I propose distinctive higherlevel learning processes triggered by failure that prove fundamental in personal and business terms. These learning outcomes provide entrepreneurs with invaluable insights into the "pressure points" of the entrepreneurial process, significantly augmenting levels of entrepreneurial preparedness for future enterprising activity.
\end{abstract}

Keywords: Entrepreneurial learning, venture failure, grief recovery, phenomenological, action learning. 


\section{Entrepreneurial learning from failure: An interpretative phenomenological analysis}

\section{Executive summary}

There has never been a more apposite time to develop a deeper understanding of venture failure. The continuing global economic downturn has created an extremely challenging environment for entrepreneurs, with many economies witnessing a sharp increase in business failure rates. For many entrepreneurs failure remains a very real prospect. Academic work needs to reflect this rapid change in fortunes, warranting a much more prominent position for failure in contemporary discussions of entrepreneurship. With so many businesses failing it is vital to understand further how entrepreneurs recover and move on from this often painful and damaging experience and thereby highlight the positive and productive lessons that failure can engender. Moving beyond the causes of venture failure, this paper seeks to develop a richer picture of the impact and outcomes of failure and build a more informed learning perspective of this prominent entrepreneurial phenomenon.

Whilst failure is lauded as a fundamental learning experience, theorists have acknowledged that this view of failure is often espoused in popular management literature that bases its assertions on anecdotal evidence. There remains a paucity of academic studies that seek to articulate failure at the level of lived experience and ground theoretical discussions in rich qualitative accounts. This paper seeks to address these concerns and provide a novel interpretative phenomenological analysis of failure. In so doing, the paper adds much needed empirical weight to the proposition that failure represents a learning journey for entrepreneurs. Building on theories of grief recovery, I complement and extend this perspective by examining distinctive learning dimensions of the grief recovery process. Drawing on established theoretical frameworks from adult and management learning literature, conceptual links are built between different orientations to grief recovery and specific learning processes, including critical reflection and reflective action. This enables me to propose higher- and lower-order forms of restoration orientation that enable entrepreneurs to recover from failure more effectively.

Significant advancements have been made in conceptualising the process of entrepreneurial learning, particularly in relation to critical events. I seek to reconcile the growing literature on entrepreneurial learning with that of venture failure, applying a more rigourous entrepreneurial learning lens to appreciate both the process and content dimensions of learning from failure. I demonstrate that failure represents a higher-level learning experience that fosters three distinct forms of entrepreneurial learning; learning that proves fundamental in both personal and business terms. The research suggests that failure can produce future-oriented learning outcomes that increase the entrepreneur's level of entrepreneurial preparedness for further enterprising activity. 
Whilst the how of entrepreneurial learning has attracted much attention, less is currently known about the specifics of what entrepreneurs learn and this research gap applies to venture failure. Drawing on an established entrepreneurial learning framework, this paper provides a thematic analysis of the content dimensions of learning from failure. I highlight that entrepreneurs not only learn much about themselves and the demise of their venture but also about the nature of relationships, the wider environment and the "pressure points" of the entrepreneurial process.

The paper draws on the experiences of entrepreneurs from both the UK and the USA. The aim is not to juxtapose but rather to establish patterns and covergence, to identify a common learning process from failure that can enable more fine-grained comparative research. Whilst there are likely societal implications for how entrepreneurs recover and learn from failure, I do not seek to make such macro-level distinctions using a qualitative sample. Ultimately, the aim is to develop a theoretical model of learning from failure that identifies key stages in the entrepreneurial learning process.

The paper has a number of significant implications. First, the research complements theories of grief recovery by illustrating that moving on from failure is not only a function of overcoming the financial and emotional costs of failure, but also the relational costs. Recovering from failure has much to do with repairing the damage caused to private and professional relationships. However, the paper demonstrates that failure does not necessarily produce any long-term negative professional consequences, with key stakeholders accepting that failure is a fact of life in the startup community. This provides encouraging signs to entrepreneurs who are concerned about the possibility of receiving future support for their ideas as failure is not automatically considered a "black mark" by other professionals.

Second, the research highlights the significance of social and environmental feedback both during and after failure in helping entrepreneurs to grieve and put the failure into perspective. Affirmative further action, including the positive personal and social feedback that this provides, speeds the recovery process and re-establishes working relations. Conversely, prolonged critical self-reflection and introspection can be unhelpful. Such reflective action represents a "higher-order" restoration orientation as it fosters a future-oriented perspective that can reenergise the entrepreneur and enable learning outcomes from failure to be enacted.

Third, I propose new forms of learning-oriented failures that extend beyond existing literature on "intelligent" failures, in which it is proposed that failures which only modestly challenge existing assumptions make learning more likely. The paper disputes this perspective and conceptualises transformative, generative and regenerative failures that can radically challenge existing beliefs; thereby creating the capacity for entrepreneurs to do things differently rather than refining the efficacy of extant behaviours and actions. Such profound learning can expand the 
entrepreneur's range of potential behaviours, revise previously ineffective routines, highlight mistakes and augment skills and knowledge about the entrepreneurial process.

\section{Introduction}

"Love the moment. Flowers grow out of dark moments. Therefore, each moment is vital. It affects the whole. Life is a succession of such moments and to live each, is to succeed" (Corita Kent).

Whilst failure is a painful and damaging experience for entrepreneurs (Whyley, 1998), extant theorising points to the substantial information, learning and knowledge contained within this experience (Cardon and McGrath, 1999; Shepherd, 2003). Although commonly heralded as a significant learning process many writings on learning from failure draw few of their propositions from meticulous and academically rigourous observations (Baumard and Starbuck, 2005). This view of failure is often espoused in popular management literature, which relies heavily on anecdotal evidence and thus 'our understanding of the conditions under which it occurs is limited' (Cannon and Edmundson, 2001: 161). I observe that learning from venture failure needs to be examined more closely to appreciate the specific forms of learning and associated outcomes that this "critical episode" can engender (Cope and Watts, 2000).

In defining failure, it is vital not to conflate failure with business closure (Headd, 2003), which may involve the voluntary termination of a venture for reasons such as retirement or the pursuit of other activities, including more lucrative or interesting entrepreneurial ventures (Stokes and Blackburn, 2002). I align myself with theorists who propose an intuitively appealing conception of failure as the termination of a business that has fallen short of its goals (McGrath, 1999; Politis and Gabrielsson, 2009), thereby failing to satisfy principal shareholder expectations (Beaver and Jennings, 1996). Moving beyond relatively narrow conceptions of failure as bankruptcy or liquidation, failure involves the loss of capital and an inability to "make a go of it" (Cochran, 1981). Hence, an unexpected fall in revenues and/or rise in expenses means that the venture cannot continue to operate under its current ownership and management (Shepherd et al., 2000; Shepherd, 2003).

Commentators emphasise that the process of learning from failure has not been clearly described (McGrath, 1999). Whilst conceptual clarity regarding failure is being achieved, there remains a paucity of qualitative studies that have sought to articulate failure at the level of "lived experience" (Blackburn and Kovalainen, 2008), to tell the entrepreneur's story (Zacharakis et al., 1999) and ground theoretical discussions of failure in rich narrative accounts (Fincham, 2002; Stokes and Blackburn, 2002). In response, I provide a novel interpretative phenomenological analysis of the process and content dimensions of learning from failure. As part of an on-going failure research programme involving the UK and the USA, this paper is based on a qualitative 
sample of eight entrepreneurs, four of whom are from the UK, whilst the remainder are from Silicon Valley, California.

The paper makes a number of important contributions. First, in advancing the learning from failure literature the research illustrates that experiencing and managing failure radically heightens levels of emotional and financial exposure. Whilst such assertions are not revolutionary, I provide vital qualitative evidence that enriches contemporary theoretical discussions of the costs of failure (Shepherd, 2009; Shepherd et al., 2009, 2008). This paper augments Shepherd's (2003) learning theory of grief recovery by illustrating additional impacts of failure, including an emphasis on social and professional consequences. Such a focus builds on the growing acknowledgement that entrepreneurial learning is an inherently relational activity (Clarke et al., 2006; Devins and Gold, 2002; Gibb, 1997; Rae, 2004; Taylor and Thorpe, 2004). The aim is to contribute towards "streams of research that can explain, at least in part, why some more successfully recover from the negative emotional reaction to the loss of a failed business than others" (Shepherd, 2009: 82).

Second, in building further on Shepherd's (2003) work I continue to conceptualise grief recovery as a learning process with particular facets, triggering higher-order learning reminiscent of an entrepreneurial learning cycle (Politis, 2005). I seek to reconcile Shepherd's more recent work on grief orientation dynamics with adult learning theory to propose two distinct forms of "restoration orientation" (Shepherd, 2009). A learning model of grief recovery is proposed that forms an integral part of a higher-level, developmental learning theory of failure that this paper seeks to build (Cope, 2003; Granott, 1998). Shepherd's (2003) model begins with the failure event and moves on to the subsequent negative emotional reaction to loss. I extend the conceptual boundaries of grief recovery as a learning process by taking a broader perspective, capturing learning across the "failure continuum" (Holmberg and Morgan, 2003) that occurs both during, and after, the grief recovery process. The overall contribution is the creation of an inductive theoretical framework that augments our appreciation of failure as a "learning journey" (Cardon and McGrath, 1999), identifying characteristic learning timeframes that include, but are not limited to, grief recovery. In this way, the research complements existing qualitatively-based process models of failure (Venkataraman et al., 1990).

Third, it is acknowledged that failure represents a very special domain in which to examine entrepreneurial learning (Politis, 2005). Failure is arguably the most traumatic yet significant trial and error entrepreneurial learning experience. Much previous research has examined the entrepreneurial learning process (Corbett, 2005; Minniti and Bygrave, 2001; Politis, 2005; Ravasi and Turati, 2005), including the process of learning from venture failure (Shepherd, 2003; 2009). Nevertheless, I maintain that greater contextual specificity can enable important contributions to be made to the rapidly emerging literature on entrepreneurial learning. There is currently scant 
empirical evidence of the content dimensions of entrepreneurial learning and the significant "learning task" outcomes associated with distinctive aspects of the entrepreneurial process (Cope, 2005a). In recognising failure as just one of many critical entrepreneurial learning contexts/processes this paper sets the stage for further research that aims to understand what it is that entrepreneurs learn as well as how they learn it.

Fourth, I move beyond the confines of the entrepreneurship field and draw on wider adult and management learning literature to inform analysis and conceptualisation. This interdisciplinary stance reflects repeated calls by entrepreneurship scholars (Blackburn and Kovalainen, 2008; Zahra, 2007) and my concern that entrepreneurial learning theory comes full circle and contributes back to wider managerial learning discussions, particularly those related to failure (Sitkin, 1992). After all, entrepreneurial learning remains a "special” form of management learning (Cope, 2003).

The paper begins by critiquing much extant research that focuses on the causes of venture failure, highlighting the need to move beyond the question of why businesses fail to appreciating the developmental significance of failure. The importance of failure from a learning perspective is then established. I proceed to articulate an in-depth phenomenological study conducted with eight entrepreneurs who have directly experienced failure. This is followed by a series of analytical data sections that provide an empirical analysis of failure as a learning journey, exploring the immediate negative impact of failure and moving on to more positive learning outcomes. This enables the inductive development of two theoretical models of learning from failure, the first of which illustrates the learning processes associated with grief recovery, whilst the second demonstrates the distinctive learning timeframes of failure. The paper continues by examining the theoretical implications of the study and proposing a number of areas for further research, including a more explicit focus on the relational dynamics of learning from failure. Finally, I contemplate the use of action learning as a peer-to-peer learning mechanism that may be useful in facilitating a more participative approach to learning from failure.

\section{Theoretical overview}

\subsection{Re-thinking entrepreneurial failure}

It is obvious that failure is not an inherently desirable outcome of entrepreneurial activity. In many cases failure can be painful and costly (Coelho and McClure, 2005), having a negative impact on the entrepreneur's confidence, self-efficacy and risk-taking propensity (Cave et al., 2001; Shepherd, 2003). Singh et al. (2007) identify four aspects of life affected by failure which are defined as economic, social, psychological and physiological. Whyley (1998) provides compelling qualitative accounts of small business failure in the UK, demonstrating the significant damage it can cause in physical and psychological terms, undermining the entrepreneur's self-esteem and the 
relationships they have with other people.

Although venture failure is an unequivocal feature of entrepreneurial life, entrepreneurship theory often reflects an antifailure bias (McGrath, 1999) due to a strong tendency to focus on successful organizations (Denrell, 2003). Perhaps this is a manifestation of the premise that we generally do not like to fail (Gupta, 2005). From a societal perspective, Scott and Lewis (1984) argue that the general tone has followed the cultural norm that failure is a negative event and that "the old moral imperatives come through to us: failure is bad, failure is a breakdown in social relationships to be guarded against" (1984: 34). Not only are individuals primed to avoid failure because of fears of stigmatisation (Sitkin, 1992; Cave et al., 2001), but many researchers mourn the cost of failure and attempt to root out its causes so that it can be prevented (McGrath, 1999). The work of Fredland and Morris (1976) still has resonance when they state that "the search for the causes of failure is in fact largely a matter of ascribing blame. If the 'fault' can be pinpointed, policy can presumably be properly directed. The term 'underlying cause' connotes blame and the effect of limiting underlying causes to, or near, the poor management extreme is to ascribe most failures to internal causes" (1976: 8).

In their review of firm-level empirical studies of failure, Thornhill and Amit (2003) confirm the common perception that a lack of management and financial planning skills are the most common causes of firm mortality. They reinforce this position by blaming the "liability of newness" associated with young firms on the inexperience and managerial deficiencies of the entrepreneur. Whilst this indeed may be the case (Jennings and Beaver, 1995), what is conspicuously absent from many such studies is any form of reflexivity in considering the potentially harmful impact of these assertions, particularly on those individuals pursuing an entrepreneurial career. Stokes and Blackburn (2002) argue that this over-focus on cause and prevention is diverting attention away from more significant areas of inquiry, particularly the learning dynamics of failure. There is a need for theorists to move beyond the lingering question of why most firms die young (Cressy, 2006) and accept that making mistakes, even those that lead to venture failure, is part and parcel of the entrepreneurial (learning) process.

This dominant antifailure bias can interfere significantly with the entrepreneur's ability to make sense of this traumatic episode (McGrath, 1999). As Shepherd (2003) illustrates, feelings of guilt, shame, embarrassment and self-blame are just some of the negative emotions that entrepreneurs experience as a result of failure. By continuing to focus attention on the underlying causes of venture failure and apportioning blame little is being done to alleviate these emotions and help entrepreneurs recover and successfully move on from failure. Rather, the negative connotations and stigma associated with failure are being perpetuated and the beneficial aspects of this experience obscured. As Cannon and Edmundson (2001) stress, individuals associated with 
concrete instances of failure fear being stigmatised and such concerns are not irrational. In redirecting research towards a more developmental and progressive perspective, the defining stance of this paper is that "failure should be treated more as an episodic event from which a great deal can be learned and less as an indication of 'unfitness' to manage” (Gaertner, 1988: 316).

Given such undesirable perceptions of failure, individuals and organizations often focus on success and avoid the possibility of failure, which can lead to errors in learning and interpretation (McGrath, 1999). In contrast to failures, drawing lessons from successes is much more difficult as success does not create an urgent need to enrich current knowledge structures or behaviours; rather it reinforces existing beliefs and routines (Ellis et al., 2006). Through repeated success "we become myopic and ignore changes that do not suit us" (Gupta, 2005: 3). Consequently, success has the ability to "breed failure" (Mellahi and Wilkinson, 2004), by creating fundamental problems such as structural and strategic inertia, decreased organizational resilience, and managerial overconfidence, complacency and insularity (Baumard and Starbuck; 2005). Rerup (2005) goes so far as to argue that entrepreneurs who "mindlessly" transfer and replicate successful business models from one situation to another are likely to fail. Fundamental forms of reflection and learning, and more radical experimentation and innovation, are therefore more likely in relation to failure rather than success (Ellis and Davidi, 2005; Sitkin, 1992).

\subsection{Conceptualising failure as a "learning journey"}

A consistent message from many theorists is that failure represents an essential prerequisite for learning (Cave et al., 2001; Hill and Hlavacek, 1977; Stokes and Blackburn, 2002). Cardon and McGrath (1999) state that many entrepreneurs credit learning from past failure as a crucial element of their experience base and it is vital to recognise failure as a "learning journey." Developmentally, failure can be understood as an experience by which individuals grow into becoming entrepreneurs (Scott and Lewis, 1984). The significance of failure is that it produces a "learning readiness" that is difficult to produce without a perceived need for corrective action (Sitkin, 1992).

From a process perspective, Shepherd (2003) proposes that an integral element of learning from failure is the process of grief recovery. He argues that an individual has recovered from grief when thoughts surrounding the loss of the business no longer generate a negative emotional response. He goes on to propose two distinct approaches to grief recovery. First, a "loss orientation" that involves actively confronting the loss and associated negative emotions in order to "work through" what happened and make sense of the failure. In contrast, a "restoration orientation" is based on avoidance and suppression, purposefully distracting oneself from loss-related thoughts, allowing for the gradual fading of memories associated with the loss. Shepherd concludes that oscillation between the two models of coping behaviour is most effective in speeding the recovery 
process.

Sitkin (1992) argues that the importance of failure lies in its ability to challenge current practices and procedures by drawing attention to previously overlooked problems and inconsistencies; fuelling an "unfreezing" process in which old ways of perceiving, thinking and acting are shaken and new ways accommodated. Such "mindfulness" encourages the creation of new meaning perspectives and occurs more frequently when tending to the unfamiliar or deviant (Mezirow, 1991). It is apparent then that failure can reduce an entrepreneur's "epistemic blind spots" (Choo, 2008). Such perceptual flaws are precursors to disaster as they prevent the recognition of warning signals that conflict with habitual beliefs (ibid). The increased vigilancy and responsiveness created by these "mindful" outcomes of failure (Rerup, 2005) are consistent with higher-level forms of learning, which involve the radical questioning and revision of underlying assumptions, frames of reference and mental models that guide one's actions (Foil and Lyles, 1985; Kim, 1993).

Entrepreneurial learning theory has established that discontinuous experiences during the entrepreneurial process can stimulate distinctive forms of learning that prove fundamental to the entrepreneur in both personal and business terms (Cope and Watts, 2000; Deakins and Freel, 1998; Taylor and Thorpe, 2004). Experiencing such non-routine events can contribute substantially to the entrepreneur's subjective stock of knowledge (Minniti and Bygrave, 2001; Reuber and Fischer, 1999). Cope (2003) illustrates that critical incidents can create "double-loop" learning outcomes regarding organizational theories for action (Argyris and Schön, 1978), but also engender deeply personal "transformative" personal learning that relates to self-awareness (Mezirow; 1991). As venture failure is, arguably, the most fundamental and challenging critical experience that the entrepreneur may face (Cope, 2005a; Politis, 2005), these particular forms of higher-order learning have clear relevance in appreciating its developmental significance. I therefore see it as vital to draw on contemporary entrepreneurial learning literature, and wider learning frameworks, to build a more integrated understanding of the relationship between entrepreneurial learning and failure.

There is a vital future-oriented element to learning from failure, in that this experience is seen as invaluable in understanding alternative and more effective ways of acting in the future (Zacharakis et al., 1999). Experiencing failure has also been found to lead to more positive attitudes to failure (Politis and Gabrielsson, 2009). As Ellis et al. (2006) stress, failures are the "fuel that intensifies cognitive processes" (2006: 670), enabling learners to improve future performance, predict potential critical events and respond accordingly. Studying and learning from failure can help entrepreneurs to avoid falling into unreflective cognitive ruts or "learning traps" (Rerup, 2005; West and Wilson, 1995), especially those who are able to learning vicariously from the experience of others (Denrell, 2003; Thornhill and Amit, 2003). Hence, entrepreneurs who actively process a 
failure event are in a "unique position to start a successful new business" (Shepherd et al., 2009: 142). Timmons (1999) is more forthright in his claims, reinforcing the eulogised view of failure as a necessary step to success. "In order to succeed one first has to experience failure. It is a common pattern that the first venture fails, yet the entrepreneur learns and goes on to create a highly successful company" (1999: 30; italics added). Whilst this is a rather contentious assertion that has entered into the realms of failure mythology, it is apparent that success and failure are deeply intertwined in both meaning and action (Coelho and McClure, 2005; Fincham, 2002). I put aside such compelling rhetoric and seek to achieve a rich phenomenological appreciation of failure as it is "lived", from the grounded perspective of those who have experienced it directly (Berglund, 2007; Cope, 2005b; Seymour, 2006).

Shepherd (2003) emphasises that in order for learning from failure to be useful the knowledge gleaned must be applied to another business. Application and utilisation appears important in the process of learning from failure (Cope, 2005a). Commentators contend that failure can increase an entrepreneur's probabilities of success, using it as an instrument to learn "what works and doesn't work" (Sarasvathy and Menon, 2002: 9). Failure is described as a "stepping stone" to spot new opportunities and improve business processes (Gupta, 2005; Politis, 2005). In essence, entrepreneurs who have learned from failure are more motivated to start another enterprise and feel more prepared due to the lessons learned (Stokes and Blackburn, 2002). Not only are entrepreneurial intentions maintained, but many go on to become successful serial entrepreneurs (Sarasvathy and Menon, 2002; Schutjens and Stam, 2006). This is not to imply that all entrepreneurs cannot succeed without first facing failure, as Timmons (1999) would have us believe. Rather, what is apparent is that failure has the capacity to create higher-level "generative" learning outcomes, as entrepreneurs are able to bring forward their learning from this experience to abstract and generalise across new business contexts (Gibb, 1997). Cope (2005a) argues that such generative learning outcomes are highly valuable and productive as entrepreneurs can develop a “cognitive early warning system", enabling anticipatory corrective actions to be taken in subsequent ventures (Politis, 2008).

Sitkin (1992) makes the crucial recognition that not all failures are equally adept at facilitating learning and introduces the concept of "intelligent failures", which are small and relatively harmless failures most effective in fostering learning. Learning from failure is not always automatic or instantaneous (Scott and Lewis, 1984; Wilkinson and Mellahi, 2005). Theorists point to the significant psychological and emotional barriers to learning that can accompany a failure experience. These barriers can be self-imposed due to associated pain, grief and remorse (Cardon and McGrath, 1999), but also because confronting failure and one's potential culpability can be a daunting prospect (Cannon and Edmundson, 2001; Rogoff et al., 2004). Additional barriers are 
socially situated and relate primarily to fears of stigmatisation (Cannon and Edmondson, 2005; Savitsky et al., 2001). As Baumard and Starbuck (2005) emphasise, a reluctance to admit to failure jeopardises an individual's opportunity to engage in effective relational learning.

Ultimately, commentators emphasise that the process of learning from failure has not been clearly described (Shepherd, 2003) and a detailed understanding of this phenomenon remains elusive (McGrath, 1999; Zacharakis et al., 1999). In responding to calls for a more "micro-level" perspective of venture failure (Shepherd et al., 2000), I proceed to develop a qualitative appreciation of failure as a "developmental" learning experience (Stokes and Blackburn, 2002), conceptualising both process and content perspectives.

\section{Research methodology}

Reinforcing the vital acknowledgement that qualitative inquiry should not be the "special case" within the entrepreneurship domain (Gartner and Birley, 2002), this paper is based on interpretative phenomenological research with eight entrepreneurs. Such approaches are gaining momentum within the entrepreneurship domain (Berglund, 2007; Cope, 2005b; Seymour, 2006), but have yet to be applied to the subject of learning from failure. This methodological stance locates the study within an emergent body of entrepreneurship scholarship that is confident in utilising qualitative methods as its only form of inquiry/analysis (e.g. Anderson and Jack, 2002; Drakopoulou Dodd, 2002; Kisfalvi, 2002; Rae, 2000). This includes a vibrant stream of entrepreneurial learning research (Deakins and Freel, 1998; Pittaway and Cope, 2007; Ravasi and Turati, 2005; Taylor and Thorpe, 2004) and a growing number of failure studies (McKensie and Sud, 2008; Mellahi, 2005; Mouly and Sakaran, 2004; Sheppard and Chowdhury, 2005; Singh et al., 2007; Venkataraman et al., 1990; Zacharakis et al., 1999). As Jack and Anderson (2002) emphasise, the strength of a qualitative research design "lies in its capacity to provide insights, rich details and thick descriptions" (2002: 473). As part of an on-going comparative research programme between the UK and the USA, the aim of the study was to develop a detailed phenomenological conceptualisation of the "lived experience" of failure (Thompson et al., 1989). In moving beyond the causes of failure, the research seeks to provide " theoretical insight" (Mouly and Sakaran, 2004) into the impact and outcomes of failure from the entrepreneur's perspective; to appreciate what it feels like to experience and move on from the loss of a venture. The study draws on the principles of Interpretative Phenomenological Analysis (IPA) developed by Jonathan Smith and colleagues (c.f. Smith et al., 1999) to inform both research design and analysis.

\subsection{Sample selection}

IPA sampling is "purposive" (Greening et al., 1996) and this methodology defends the use of small samples, enabling a competent theoretical perspective to be developed as long as adequate 
contextualisation is preserved (Brocki and Wearden, 2006; Chapman and Smith, 2002). ${ }^{1}$ A distinctive feature of IPA is a commitment to producing a fine-grained interpretative account that is grounded in, and does justice to, each participant's unique lived experience (Smith and Osborn, 2008). Six to eight is recommended as an appropriate number of participants for a typical IPA study (Smith and Eatough, 2006). Work on entrepreneurial learning has demonstrated that rich substantive theory can be developed using such a small sample size if a strong phenomenological grounding in the "lived-world" of the participants is achieved (Cope, 2003; Ravasi and Turati, 2005). As Smith and Osborn (2008) emphasise, IPA researchers must be pragmatic in choosing participants, particularly where the topic under investigation is rare and issues of accessibility and willingness to participate are problematic. Such is the case with venture failure, as identifying entrepreneurs who have disclosed a failure and are willing to openly share their experiences in a research setting is no easy matter (Sarasvathy and Menon, 2002; Zacharakis et al., 1999). Opportunism and convenience were contributing factors in choosing the purposive sample for this study (Patton, 1990). Potential for learning was therefore used as a superior criterion to representativeness in terms of either population or probability (Stake, 1994). Ultimately, it was assumed that any participant who had experienced the phenomenon of failure directly would have a highly engaging and pertinent story to tell (Fincham, 2002). In relation to the eight entrepreneurs represented such assumptions were not unfounded.

Sample construction has been informed by a failure study that has utilised matched samples (Zacharakis et al., 1999) and a phenomenological investigation that has explored the attitudes to failure of venture capitalists (Cope et al., 2004). The present sample consists of four entrepreneurs that are geographically spread throughout the UK (Gill, Nick, Colin, Ben), whilst the remaining four American participants are based in Silicon Valley, California (George, Tom, Jake, Hugh). Table 1 provides an anonymised profile of the participants. Within this purposeful sampling strategy, snowball or chain sampling was also used (Hartley, 1994). The UK participants were identified through personal networks of the authors, whilst the US participants were recommended by a contact in a venture capital firm that had been involved with the failed ventures. Pragmatically, issues of convenience in terms of location and travel shaped the decision to choose participants from Silicon Valley. As the research was purposely designed and conducted shortly after the 'dot.com' bubble had burst, I envisaged that finding entrepreneurs with a failure experience would (sadly) be easier.

1 In purposive sampling participants are chosen because they exhibit particular features or experiences (in this case failure), that will enable a detailed understanding of the central themes and puzzles the researcher wishes to study. It is also described as "judgement" sampling (Marshall, 1996) or "criterion based" sampling (Mason, 2002). As Patton (1990) states, "the logic and power of purposeful sampling lies in selecting information-rich cases for study in depth. Information-rich cases are those from which one can learn a great deal about issues of central importance to the purpose of the research, thus the term purposeful sampling" (1990: 169). 


\section{PLEASE INSERT TABLE 1 ABOUT HERE}

Whilst some diversity was inherent in the sample in terms of industry and timing of the failure, particularly for the UK participants, it was recognised that a great deal of variablility would reside at the phenomenological level and remain inaccessible until engagement in the field (Cope and Watts, 2000). More practically, given the difficulties encountered in finding willing participants and the sensitive nature of the research, during initial telephone contact the authors were grateful just to obtain permission for an interview. It was deemed inappropriate to delve too deeply into the participant's background, the venture, or the circumstances of the failure until face-to-face contact was achieved. This was especially the case with the USA participants, with whom the author was completely unfamiliar. This meant that I was reluctant to restrict the sample in terms of the time elapsed since the failure (e.g. within the last five years) as I was only too aware of how hard participants can be to come by.

Furthermore, it has been established that learning from critical episodes such as failure is a dynamic and perpetual process, with entrepreneurs continuing to experience changes in awareness long after the event itself (Boud et al., 1993; Cope, 2005a). When the failure happened was therefore less important than whether the participants could still clearly recall what happened, what impact the failure had and what they learned from the experience. As a result, for some of the participants the failure happened a few years ago whilst for others it was many years. The point to stress is that regardless of how long ago the failure occurred it remained extremely vivid, thereby highlighting its lasting significance. This could be viewed as a methodological limitation, but it is hoped that the findings presented demonstrate otherwise. For all the participants, the data demonstrates that the lived experience of failure, including its positive and negative outcomes, remains visibly and fundamentally meaningful.

The credibility and strength of IPA sample selection rests on theoretical (rather than empirical) generalizability (Ram et al., 2006) and in finding participants for whom the research question is pertinent and whose experiences illuminate the phenomenon in question (Brocki and Wearden, 2006; Chapman and Smith, 2002). The 'local knowledge' generated avoids what Steyaert (1997) describes as 'acontextuality'. Above all, it is for the reader to judge if this research design "worked", which rests on one's ability to emphathise with, and make connections between, the data presented and analysed, one's own personal and professional experience, and the author's interpretative engagement with extant literature (Smith and Osborn, 2008).

\subsection{Fieldwork strategies}

"Phenomenological interviewing" (Thompson et al., 1989) was the primary methodology used during the fieldwork phase of the study. Thompson et al. (1989) provide a detailed description of 
what they term "phenomenological interviews", which are described as "the most powerful means of attaining an in-depth understanding of another person's experiences" (1989: 138). The goal of the phenomenological interview is to gain a first-person description of some specified domain of experience, where the participant largely sets the course of the dialogue (Cope, 2005b). Following this approach, the interviews were "loosely structured" (Thompson et al., 1989). As Thompson et al. (1989) state, with the exception of an opening question, the phenomenological interviewer must have no a priori questions regarding the topic. The interview began with a broad question - "Can you tell me about your experience of failure?" Subsequent questions derived from the dialogue. This form of interview has strong similarities to the "depth interview" (Jones, 1985) and the "informal conversational" interview (Patton, 1990), where "questions emerge from the immediate context and are asked in the course of things; there is no predetermination of question topic or wordings" (ibid: 288).

\subsection{Data analysis}

Demonstrating rigour through a careful and comprehensive articulation of data analysis is a critical issue in improving the robustness of qualitative entrepreneurship research. As Bryman (2004) points out, too few studies elaborate on their method of data analysis. As a new and developing approach to understanding the nature of lived experience, IPA provides a clear set of thorough and accessible guidelines. IPA is not a prescriptive methodology and allows for individuality and flexibility of approach (Smith and Eatough, 2006). IPA is systematic in its procedures, but whilst "there is a basic process to IPA (moving from the descriptive to the interpretative), the method does not claim objectivity through the use of a detailed, formulaic procedure" (Brocki and Waerden, 2006: 97). Drawing on and adapting the principles of IPA developed by Jonathan Smith and colleagues (c.f. Smith et al., 1999), together with Hycner's (1985) seminal work on the phenomenological analysis of interview data, I specify the different levels of analysis and interpretation applied to the eight fully transcribed interviews. IPA is emphatically inductive and idiographic, starting with a detailed, nuanced analysis of one case and then moving to the meticulous analysis of subsequent cases (Smith, 2004). Table 2 outlines the different levels of interpretative phenomenological analysis conducted.

\section{PLEASE INSERT TABLE 2 ABOUT HERE}

To enable the reader to develop a detailed appreciation of the participants' experiences and to allow their voices to be heard (Eccles, 2000), the analytical findings include a lot of engagement with, and direct quotations from, the empirical material generated from the interviews. Relevant literature is enfolded throughout to enable stronger credibility and deeper conceptual insight (Eisenhardt, 1989). Interpretation and theory-building are an integral part of the findings presented. 
I acknowledge that this involves a difficult trade off as enfolding literature does, to some extent, marginalise the voices of the participants, but remains essential if the research is to make useful theoretical contributions to contemporary debates. I also recognise that using qualitative research techniques and small samples inhibits generalisability (Anderson and Miller, 2003; Kisfalvi, 2002). Cognisant of these challenges, I seek to create 'local' knowledge that provides fine-grained processual accounts (Steyaert, 1997) examining intra- and inter-case processes and dynamics (Ram et al., 2006). Theory-building can therefore be envisaged as evolutionary and iterative, with room for continuous improvement through application in similar/different contexts (Lincoln and Guba, 1985). The outcomes of this analytical process are developed in a series of emergent themes presented in the following data sections. The analytical presentation of findings will be followed by a discussion that focuses on theoretical implications, policy and support implications and areas for further research.

\section{Findings}

The following analytical data sections explicate both the process and content dimensions of failure. To make a rich qualitative contribution to the conception of failure as a learning journey (Cardon and McGrath, 1999), the findings present a dynamic appreciation of learning as an essential component of the failure continuum (Holmberg and Morgan, 2003). As the main aim is to explore the impact and learning outcomes of failure, a detailed consideration of causes and managerial strategies is beyond the scope of this paper. The following sections explore the immediate negative impact of failure and then proceed to how the participants moved on from, and ultimately learned from, the demise of their ventures.

\subsection{The negative impact of failure}

Failure is complex phenomenon that can have a serious and detrimental impact on numerous aspects of an entrepreneur's life. Table 3 illustrates a number of spheres in which failure can take its toll. The substantial financial costs of failure are clearly expressed here and, whilst critical, I will not dwell on this issue. Instead, I seek to illuminate contemporary conceptual discussions concerned with the emotional costs of failure (Shepherd et al., 2009), an issue still requiring considerable development (Shepherd, 2004). The experiences of the participants reinforce the recognition that, in many instances, venture failure can be equated with the breakdown of an intimate relationship (Shepherd, 2003) or a bereavement (Whyley, 1998), with overwhelming feelings of grief and loss and a questioning of "where did it all go wrong?" The affective competent of failure is a consistent and dominant theme, repeatedly described as a painful and emotionally exhausting "shock to the system". In building on Shepherd's (2003) concept of grief as a negative emotional response to the loss of a business, the data emphasises the significant social dynamic of grief, reinforcing the 
intricate interplay between the affective and relational characteristics of entrepreneurial learning (Cope, 2005a). Specifically, the emotionality of failure is linked to feelings of social responsibility and the associated stress that this can create. These social pressures come from a range of sources, including investors, employees, creditors and family, as George expresses:

"It's a very lonely job...the hardest part is that you do feel responsible...to the people who work for you, the people that invested in you, your customers who gave you money for things that you can no longer do".

As this comment illustrates, feelings of guilt and impotence, in turn, can exacerbate a sense of loneliness and isolation as the entrepreneur feels unable to turn to others in order to share their anxieties, alleviate stress and ameliorate how desperate the situation feels. The only person who appears to shoulder some of this distress is the entrepreneur's domestic partner and, as the quotes in table 3 show, failure can place severe strains on this intimate relationship, even to the point of absolute collapse. Singh et al. (2007) have presented similar findings, with three out of their five participants reporting that their marriage collapsed as a result of failure. Whilst the entrepreneur's domestic partner has been identified as a vital "sounding board" in relation to entrepreneurial learning (Cope, 2005a), with regard to failure these individuals appear to occupy a more complex and difficult role, which in itself is an issue worthy of further research. Gill clearly expresses feelings of isolation:

"There was nobody around me to tell me any different...nobody who could kind of say to me

'well look, you're not a failure, you tried and you failed"'.

\section{PLEASE INSERT TABLE 3 ABOUT HERE}

In concordance with current theorising, the "entrepreneurial" impact of failure outlined in table 3 illustrates that failure can have a seemingly negative impact in terms of self-efficacy and risk-taking propensity. Echoing Shepherd's (2003) sentiments, further research is required to understand the relationship between losing a business and entrepreneurial self-efficacy. As will be demonstrated subsequently, this is a complex issue and experiencing failure can, at the same time, lead to many positive learning outcomes. This apparent duality is captured succinctly by Tom when he states that:

"I still consider it one of the best periods of my life and in some ways one of the worst periods of my life".

Given the recognition by several theorists that failure can leave a durable stigma (Morrison, 2000) from which some individuals are unable to recover (Deakins, 1996), the research produces divergent and appealing findings. None of the participants felt that experiencing failure has had any long-term negative impact at a professional level and all have been able to retain credibility and legitimacy with investors (Shepherd et al., 2009), as Tom articulates:

“A few people have said...that you've really been through both sides of it and I like that you've 
been up and down and you're still here punching and they really respect that I think".

Ben and Hugh express similar positions:

"I have never found that it has affected my ability to get work with anybody else, so from a professional point of view I suspect that other professionals accept that every now and again things don't go well" (Ben).

“The financiers, I've not had an opportunity to work with them again but I keep in contact with them and would certainly entertain working with some of their portfolio companies and they'd entertain having me there, so there isn't any sort of professional legacy or professional malice" (Hugh).

A study by Cope et al. (2004) that explores the attitudes of venture capital investors to entrepreneurs with a failure experience reinforces this perspective, with the investors taking a tolerant and supportive view of failure and accepting it as a fact of life in the start-up community. The findings indicate that only one of the participants, Gill, felt any palpable and enduring stigma associated with failure and this was largely self-imposed. Savitsky et al. (2001) indicate that when people experience a potentially embarrassing event or failure, they often expect to be judged significantly more harshly by others than is actually the case. As Gill explains, she did not want anyone to know that she had been involved in a failed venture and had never talked openly about the failure prior to being interviewed because "it probably isn't very helpful if you tell people you have had a failed venture". Singh et al. (2007) confirm that entrepreneurs can increasingly distance themselves from friends and family due to feelings of embarrassment and shame and is this clearly expressed by Gill:

"I was pretty ashamed of the whole thing really...I just couldn't explain to anybody quite how desperate things were".

Recognising the eminently social character of entrepreneurship (Zafirovski, 1999), there are powerful glimpses in the data of the social costs of failure for the entrepreneur. To summarise, these include issues of condescension, powerlessness, the damaging and repairing of professional relationships, the severe straining of personal relationships and perceived, but perhaps not tangible, stigmatisation. However, the social dynamics of failure are sufficiently complex, as the research has revealed some neutral to positive professional consequences. I propose that the "emotive encounters" (Goss, 2005) surrounding failure require much further exploration, in terms of both rehabilitation and learning. The importance of "significant others" (Cope, 2005a; Shepherd, 2009) will be returned to subsequently. Accepting the traumatic impact that failure can have on entrepreneurs and other stakeholders (Beaver, 2003), I argue that grief recovery is not only a function of overcoming the financial and emotional costs of failure (Shepherd et al., 2009), but also the relational costs. I now move on to to develop a deeper appreciation of the grief recovery process and seek to appreciate the distinctive learning processes that have helped the participants come to terms with losing their businesses and move on from the painful experience of venture failure. 


\subsection{The learning dimensions of grief recovery}

Shepherd et al. (2008) remind us that learning takes time after a failure. The findings in table 4 confirm that moving on from failure involves a healing process, a "hiatus" (Mezirow, 1991), in which to recover and grieve for the loss of one's business before purposeful learning can begin. Put simply, some measure of distance is required to overcome the very raw emotions of failure. As would be expected, the participants experienced heteregenous "grief recovery times" (Shepherd, 2009), but all expressed similar views. It is apparent that the participants could not effectively analyse the failure immediately and actively avoided doing so, due to its painful consequences and associated negative emotional response. For some participants this was a matter of weeks or months, whilst for others this was several years. The sheer exhaustion, both mental and physical, experienced by the participants indicates that they simply did not have the energy to confront the loss, which in itself is a physically and mentally challenging process (Shepherd, 2003).

\section{PLEASE INSERT TABLE 4 ABOUT HERE}

Different forms of "grief orientation" therefore become evident (ibid). In adding to our understanding of the distinctive orientations to grief recovery, it seems that "restoration-oriented" dynamics played a more prominent role immediately after the event. This involves undertaking activities that prove a distraction from thinking about the loss of the business, such as "playing sport, [or] odd jobs around the house" (Shepherd, 2009: 86). In learning terms this can be conceived as a "haitus", a purposeful break from thinking about what has happened (Mezirow, 1991). As table 4 discloses, this is most evident in Tom's initial recovery period following his loss, in which he obviously needed to divert attention from loss-related thoughts. In contrast, engaging in a determined "loss-orientation", which requires an active "working through" of failure to construct meaning and regulate emotions (Shepherd, 2003), in some cases took several years, as Ben's comment illustrates. Similarly, Gill states that it took two years to get through what she describes as a highly emotional "loss transition". In these cases, the continuing affective component of failure interfered significantly with the participants' ability to effectively and rationally process the event (Shepherd et al., 2008).

In marrying theories of failure with wider learning frameworks the research indicates that a "loss orientation", which culminates in fundamental changes in self-perception (Shepherd, 2003), is delicately intertwined with a cogent form of reflection, described as inward critical self-reflection (Cope, 2003; Kemmis, 1985). This specific form of fundamental reflection questions personal behaviours, assumptions and taken-for-granteds (Marsick and Watkins, 1990). Mezirow (1991) equates such reflection with "mindfulness", which involves trying to garner new information and focusing on process rather than outcome, ultimately leading to a better self-concept and more reflective action. In times of crisis, theorists confirm that reflection becomes more powerful and 
challenging and has a strong future-oriented element that leads to more effective future practices (McGill and Beaty, 1995).

The comments by Hugh and George in table 4 express the deeply personal and challenging questions that they asked themselves in order to make sense of the failure and explore the efficacy of their actions. Interpretation suggests that these participants engaged in an introspective "afterevent review" (Ellis and Davidi, 2005), investigating the failure and their own culpability. As Ellis et al. (2006) state, such reviews start "with making attempts to find an explanation for the experienced event. This allows learners not only to understand what happened in the particular event but also and mainly to enable them to predict further events and respond accordingly (in terms of feelings, attitudes and behaviours)" (2006; 670). I argue that entrepreneurs do not mindlessly attribute failure to external causes as is often purported (Rogoff et al., 2004). Rather, the data illustrates that they can be willing to examine whether any personal mistakes contributed towards the failure (Zacharakis et al., 1999) and thereby reach a more considered and productive conclusion.

Shepherd (2009) argues that, after extended use, a loss orientation will diminish the ability to learn and act. The research provides empirical support for this hypothesis, as illustrated in table 4. There is a clear recognition from the participants that dwelling on the failure and engaging in too much reflection and introspection can be unhelpful. Instead, it is important to be "mature" about it and put the failure into perspective. This is consistent with the premise that challenging forms of reflection are better linked to, and supported by, affirmative further action (Boud et al., 1985). The participants stress the importance of moving on to new activities (be they entrepreneurial or not), and this appears to be a positive dimension of a restoration-orientation rather than focusing on secondary stressors (Shepherd, 2003). This ability to move beyond the grieving process and accept failure is examined further in the next section.

\subsection{Accepting failure}

In contributing to a research agenda that examines why some entrepreneurs recover from failure more quickly than others (Shepherd, 2009), an interesting finding is that for the participants who experienced a prolonged grieving process (Ben, Gill and Tom), this was the failure of their first venture. In contrast, the other participants seemed to recover more easily as they had previously built successful ventures, and this prior experience enabled them to realise that "an isolated failure doesn't represent a repudiation of the entrepreneur's general ability" (Zacharakis et al., 1999: 10). None of the participants feel that they were personally a failure, reflecting the recognition that venture failure should not be equated with entrepreneurial failure (Cope et al, 2004; Sarasvathy and Menon, 2002), where those with a failure experience are relegated to the stigmatised category of 
"failed" entrepreneurs (Stokes and Blackburn, 2002). However, even those without previous entrepreneurial experience were eventually able to make this important distinction, with Gill stating that she now accepts that "you can have a failed venture without being a failure". However, prior entrepreneurial success seems to have much to do with the speed with which entrepreneurs can rationalise the failure and extricate themselves from the powerful emotional restraints imposed by this experience of loss. As George emphasises:

"I had other successes so I'm here because of prior success and you can't do five start-ups in a row and have them all be successful. It just doesn't work that way...there is some element of a statistical flip of the coin ".

A clear message from the participants is that failure represents a prominent and sometimes inescapable feature of the entrepreneurial landscape (Aldrich and Martinez, 2001; Gorman and Sahlman, 1989), adopting a mindset that failures are "consistently inherent in entrepreneurial endeavours, and that the optimum strategy is to live with them and learn from them" (Politis, 2008; 485). This issue is developed in the following section, in which all of the entrepreneurs in this study articulate demonstrable learning outcomes that highlight the developmental significance of failure.

\subsection{The learning outcomes of failure}

To build a robust appreciation of learning from failure, it is vital to not only examine process issues, but also the specific forms of learning and learning content derived from this experience. Based on Cope's (2005a) dimensions of the entrepreneurial learning task, table 5 illustrates the distinctive and diverse higher-level learning outcomes of failure, together with underlying learning processes. It is important to be aware that differentiating between different forms of higher-order learning is extremely difficult (Cope, 2003) and relies to some extent on the subjective assessment of the analyst (Sadler-Smith et al, 1999). Hence, there is some degree of fluidity and overlap between these learning processes.

\section{PLEASE INSERT TABLE 5 ABOUT HERE}

The importance of failure as a fundamental "trial and error" entrepreneurial learning experience (Gibb, 1997; Politis, 2005), which can be used as an instrument to increase the probabilities of future success (Sarasvathy and Menon, 2002), is clearly expressed by Jake:

"I disagree with the word, it's not failure, it's experiments. To me there's no such thing as failure,

to me you learn stuff that works or doesn't work...so the fact is when you're growing and when you're learning, when you're doing it, you can't have experience without paying your dues".

In concurrence with current theorising, the data illustrates the failure can provide learning outcomes that are impossible to obtain if one has only experienced success. Tom stresses that entrepreneurs who have only been lucky enough to build successful ventures are not necessarily that knowledgeable about the inherent challenges of entrepreneurship:

“They haven't seen anything because they haven't been through both sides of it...unless you've 
been down the other side you don't understand what the pressure points are".

Colin expresses similar views and illustrates that continued success can create "epistemic blind spots" (Choo, 2008) that breed over-confidence and complacency:

"You only learn from mistakes...because [I've been] faced with absolute failure before, got through that and got out the far side of that, that was far better learning, ten times more learning. You learn much more from failure...I mean just success coming along is just waiting for that big disaster to get you, because you're not thinking and whole bits of your brain shut down. You think you're invincible, you think you're Teflon coated and you're not. Something will come along and bite you" (Colin).

In concurrence with Stokes and Blackburn's (2002) findings that the most important learning from closure relates to issues of personal development, the participants stress that this experience has prompted a renewed understanding of their strengths and weaknesses, skills and abilities, and the efficacy of their approach to entrepreneurship. Both Hugh and Nick are explicit that failure has made them "grow up". There is a strong sense that the participants feel much more self-assured and competent as a result of experiencing failure and, put simply, have a much better sense of themselves. As George puts it, "I learned that my instincts were pretty good". The following comment by Hugh demonstrates the complex and intimate link between learning about oneself and one's business that is characteristic of entrepreneurship (Cope, 2003).

"So what I learned is that you have to have a more holistic approach...You absolutely have to be able to take that vision and you have got to be able to look in the mirror and convince yourself that you can actually build the vision.....and not figure that out in retrospect".

The "generative" dimension of table 5 illustrates that the participants feel better equipped to run businesses in the future (Stokes and Blackburn, 2002), expressing increased resilience if confronted with novel situations (Sitkin, 1992). The repeated reference to a better awareness of "pressure points", "warning signs" and "stresses and strains" during the entrepreneurial process is evidence of the productive and practical learning outcomes of failure. The comment by Jake that failure may "lead to something else" is also illustrative that entrepreneurs appreciate that failure may lead to positive outcomes in the long run (Politis, 2008).

To summarise, these findings have demonstrated the challenging learning journey associated with failure. To use the words of Stokes and Blackburn (2002), the participants have learned essential lessons about entrepreneurship "the hard way". I now move onto consider the theoretical and policy implications of the study and areas for further research.

\section{Discussion}

\subsection{Theoretical implications}

The research has demonstrated that the "learning journey" associated with failure is both arduous and extremely painful (Cardon and McGrath, 1999), with critical self-reflection and reflexivity 
playing a central role in turning this experience into learning (Mezirow, 1991). Failure is naturally emotive because of the detrimental impact that it can have on so many different yet interlinked spheres of the entrepreneur's life, at least in the short-term. Snell (1992) concludes that such painful "hard knocks" are an inevitable aspect of business life, but often prove to be important learning opportunities and unless construed as such, "a major source of personal and moral development is blocked" (1992: 16).

In applying a wider learning lens to build on Shepherd's (2003) influential work, figure 1 presents a learning model of the grief recovery process. In recognising entrepreneurial learning as a dynamic process of awareness, reflection, association and further action (Cope, 2005a; Politis, 2005), the model is reminiscent of a "relational" entrepreneurial learning cycle, with "active encounters" a central feature of this learning process (Burgoyne, 1995). The model emphasises the importance of social affirmation and feedback, which provides vital emotional support to the entrepreneur whilst s/he expends the considerable mental effort involved in managing a "lossorientation" (Shepherd, 2003). The model also highlights the significance of environmental feedback that occurs as the entrepreneur engages in new activities that restore confidence and put failure into perspective.

\section{PEASE INSERT FIGURE 1 ABOUT HERE}

The model builds on existing theories of grief recovery by conceptualising higher- and lower-order forms of "restoration dynamics" (Shepherd, 2009). A lower-order restoration orientation involves some form of distraction from the failure, a purposeful break or "haitus" to avoid having to confront the painful realities of what has happened. "Reflective action" entails more future-oriented and progressive restoration dynamics that are not based solely on suppression or avoidance. Rather the entrepreneur takes positive new steps in light of the failure that help bring an end to the negative emotional response characteristic of grief recovery. This absorbing new focus naturally distracts the entrepreneur from his/her previous loss. From a more stable and positive footing, the entrepreneur can then gradually engage in a less emotionally exhausting lossorientation. Considerable research opportunities remain in understanding how these social and environmental feedback loops impact on different grief orientations and how they help entrepreneurs recover more (or less) successfully from failure.

Minniti and Bygrave (2001) emphasise that an entrepreneur's history is influential and one's previous investments can constrain future behaviour. I argue that failure can constrain an entrepreneur's future behaviour quite dramatically, as the financial impact alone can force people back into paid employment or hamper their ability to start another venture. Far from constraining future actions failure can, at the same time, foster generative learning outcomes, thereby representing an invaluable addition to the entrepreneur's experiential "stock of experience" (Reuber 
and Fischer, 1999), and substantially improving levels of "entrepreneurial preparedness" for subsequent entrepreneurial activity (Cope, 2005a; Harvey and Evans. 1995; Stokes and Blackburn, 2002). Failure can expand the entrepreneur's range of potential behaviours, revise previously ineffective routines, highlight mistakes and augment skills and knowledge about the entrepreneurial process.

Within the entrepreneurial context, I argue that learning from failure extends beyond Sitkin's (1992) concept of "intelligent failures". Sitkin argues that such failures need to be small enough not to elicit a negative response and that "those actions that extend or modestly challenge existing assumptions, expertise, or strategic goals make learning from failure more likely" (1992: 246). The radical transformations engendered by entrepreneurial venture failure, which create a significant shift in the entrepreneur's attitudes, perceptions and "mindset" (Appelbaum and Goransson; 1997), stand in sharp contrast to these assertions. The learning outcomes presented here could hardly be described as modest. Rather, the higher-level learning from failure expressed in this study creates the capacity for the participants to "do things differently" rather than refining the efficacy of extant behaviour and actions (Argyris and Schön; 1978). I contend that the highly emotive grief recovery process is central to the higher-order learning processes associated with venture failure. Extending and applying existing terminology from wider learning literature, I argue for the existence of both "transformative" and "generative" failures. These terms capture the radical, rather than incremental, nature of learning from venture failure; learning that not only fosters re-conceptions of oneself as an entrepreneur but also redefines mental models of how to build successful entrepreneurial ventures. "Regenerative failures" are a specific subset of these failures, which are those that relate specifically to serial entrepreneurs who have gone on to apply lessons learned by actively reengaging in new venture creation or other entrepreneurial activities.

Although I have not explicitly examined the process of managing failure, from the data presented I feel it reasonable to take a small conceptual leap to suggest that failure represents a uniquely daunting learning task. This is because when confronted with failure for the first time, or any failure for that matter, it can be a frightening and disorienting experience. As argued by Cope (2005a), the entrepreneurial learning task and the associated concept of entrepreneurial preparedness can be viewed as cyclical-where entrepreneurs have to prepare for, and learn about, new opportunities and problems during the entrepreneurial process. More research is required to appreciate how entrepreneurs confront the learning task associated with managing failure, particularly its social dimensions, and will be the subject of future work. In terms of preliminary theorising, I maintain that confronting this learning task, combined with the learning outcomes presented here, makes this phenomenon one of the most difficult, complex and yet valuable learning experiences that entrepreneurs will ever have the (mis)fortune to engage in. 
A few words of caution are perhaps appropriate at this point. Although I conceptualise failure a highly beneficial learning experience, it is important to remember that some entrepreneurs may fail to learn from this experience due to an inability to effectively confront what happened (Scott and Lewis, 1984). Other entrepreneurs may want to think they have learned valuable lessons in order to rationalise what may otherwise be considered an unproductive period of their lives (Cannon, 1995). Entrepreneurs may also learn the wrong lessons or only those that fit in with existing beliefs (Baumard and Starbuck, 2005), thereby replicating the same mistakes in future activities (Shepherd, 2003). I therefore have to conclude that failure does not automatically lead to effective learning outcomes.

\subsection{Limitations and further research}

The opportunistic dimension of the purposive sampling strategy used in this research means that the UK participants were not all from a regional UK hub of entrepreneurial activity such as the Cambridge Cluster, unlike their US counterparts who were all from Silicon Valley. I do not see this as overly problematic. The paper is not inherently comparative in terms of nation states or regional locations and despite choosing participants from two different countries it was not my explicit intention to create such macro-level juxtapositions using a qualitative sample. In developing a more "micro-level" (Shepherd et al., 2000) learning perspective of failure the aim has been to demonstrate that learning from failure is shared by entrepreneurs regardless of physical/geographical location or nationality. I have sought to establish patterns and covergence, to identify a common learning process from failure that can enable more fine-grained comparative research. There may well be distinctive attitudes to failure and learning patterns/outcomes in Silicon Valley, and in certain markets or industries, but it is beyond the scope of this paper to delve into a detailed comparative analysis of these more nuanced learning outcomes. Previous models of failure have demonstrated significant theoretical contributions without incorporating industry effects (Shepherd et al., 2000). Rather, the focus has been the higher-level processes of learning from failure; namely, the transformative personal learning experienced by these entrepreneurs, and double-loop and generative learning outcomes regarding entrepreneurship. The key message I emphasise is the commonality of the participants, rather than any national or regional differences, with regard to the learning journey experienced in relation to failure.

In tackling the negative preconceptions surrounding failure and to provide policy makers with more informed and challenging perspectives, there is scope for future research to take a more critical stance in relation to failure. From a critical theory perspective, Willmott (1997) argues that critical reflection takes on very different character and must address the role of power in structuring and legitimising established norms. In addition, it must "explore the potential for changes that can 
challenge practices and ideologies through which established exploitation, oppression and subjection become institutionalised" (ibid: 71). These sentiments have clear resonance in relation to failure, particularly with regard to issues of stigmatisation and attribution of blame. It is important for future inquiry to "re-think" failure (Scott and Lewis, 1984) by examining these issues and by helping entrepreneurs, financiers and supporters to develop a more penetrating (and potentially provocative) learning stance to failure. This requires more than facilitating processes of critical selfreflection (Kemmis, 1985), but also more outward-facing critical thinking that examines wider political, social, historical and environmental forces and ideologies that shape how entrepreneurs make sense of, and learn from, failure (Gold et al., 2002; Holman et al., 1997; Reynolds, 1998). Methodologically, discourse analysis represents a useful approach to explore the language and rhetoric surrounding failure and the impact that different discourses are having at academic, policymaker, advisory and practitioner levels.

Whilst recognising the seminal work of Shepherd (2003), the "recuperative" process of recovering and moving on from failure remains a significant area for further research, which I theorise as an important "learning timeframe" of failure. In building a robust appreciation of venture failure, I contend that there are multiple learning timeframes of failure, which from a dynamic process perspective can be understood as: the build up to failure; the experience of managing failure; the impact of failure; recuperating and moving on from failure; learning from failure; and applying knowledgeable lessons to future actions and (perhaps) further entrepreneurial activity. Figure 2 provides a diagrammatic framework for appreciating this learning journey and these distinctive learning timeframes. Avenues for inquiry exist in examining each of these failure timeframes through a learning lens. It must be stressed that the perceptual, chronological and temporal boundaries of each of these phases of failure may not be easily identified as they will remain contextually and situationally unique to each individual. However, the content and processes of learning involved in each timeframe and the complex, interdependent relationships between different timeframes represent key areas for research. As Boud et al. (1993) state, "the experience itself may not change, but the learning from it can grow, the meaning of it can be transformed and the effects can be altered" (p.9). Whilst I have described "learning from failure" as a distinct learning timeframe, it is important to be mindful that learning is a dynamic, on-going process and so will take place (perhaps unconsciously to some extent) both during and beyond the failure process (Bower, 1990). Entrepreneurs may continue to reflect on, and learn from, a failure experience many years after the event itself.

\section{PLEASE INSERT FIGURE 2 ABOUT HERE}

I acknowledge that this paper has adopted an initially broad learning perspective of failure. However, the relational nature of this experience has been reinforced, reflecting wider 
acknowledgements that business venturing is communally constituted (Downing, 2005; Jack and Anderson, 2002; Down, 2006; Rae, 2004). Learning about relationships is a key feature of learning from failure (Singh et al., 2007; Stokes and Blackburn, 2002), and further research is needed to appreciate the social dimensions of failure in terms of impact, rehabilitation and learning. There remains a pressing need to examine the influence and perspectives of "significant others" at various stages of the failure process (Shepherd, 2009; Jennings and Beaver, 1995). This includes the emotional and instrumental support and advice given to entrepreneurs who are heading into or are experiencing failure, those who have recently failed but maintain entrepreneurial intentions (Stokes and Blackburn, 2002), those who have exited the entrepreneurial arena (Sarasvathy and Menon, 2002) and those who have gone on to succeed as serial entrepreneurs (Schutjens and Stam, 2006).

It is vital to comprehend the distinctive roles that different stakeholders have to play. These stakeholders include the entrepreneur's spouse/domestic partner and other family members, staff, customers and suppliers, accountants, bankers, equity financiers, formal and informal mentors, peers, advisors and friends. After all, this is the "learning environment domain" within which entrepreneurs operate (Gibb, 1997). Key research issues include their perceptions and attitudes to failure, what they have learned from being tangentially involved in a failed venture and the appreciable impact and consequences that this experience may have for them. Such a research agenda is part of a wider requirement to build a socially situated learning perspective of entrepreneurship (Hamilton, 2004).

Ultimately, this paper emphasises that failure is not confined to 'the entrepreneur' - a person so often conceived as a atomistic and monadic actor (Drakopoulou Dodd and Anderson, 2007). The ripples of failure extend in many directions and impact on many social spheres. Future studies must appreciate that, in most cases, it is the entrepreneurial family that experiences and learns to cope with failure. Longitudinal, ethnographic research would be ideally suited to tracking entrepreneurs and their families as they interactively progress through the failure process. Whilst easy to recommend, I have already argued that the greatest challenge is building diverse samples of entrepreneurs and other network actors. However, "the flip-side of these difficulties is the very real opportunity of making an important contribution to the literature and perhaps to entrepreneurs attempting to recover from business failure" (Shepherd et al., 2009: 145). I propose that one way in which researchers may build engagement, trust and social capital is by establishing action learning sets of entrepreneurs who are facing, or who have already experienced, failure. Again, finding willing participants may not be easy, but could be supported by local and regional government agencies tasked with facilitating entrepreneurship. By working with and actively trying to help entrepreneurs and their families (rather than merely treating them as research subjects), such a communal environment may create stronger bonds between researcher and participant, which in 
turn may increase access to other stakeholders. The action learning set, with permission of the participants, then becomes a vitally important research site in its own right. This issue will be developed in the following policy and support section.

\subsection{Policy and support implications}

Failure theorists argue that those who have experienced failure are likely candidates to become involved in future ventures due to increased knowledge and resilience (Politis, 2008; Saravathy and Menon, 2002; Schutjens and Stam, 2006) and so represent prime targets for those seeking to support new venture creation (Stokes and Blackburn, 2002). However, many outside agencies face significant difficulties in bringing new learning to entrepreneurial ventures (Devins et al., 2006; Fuller-love, 2006), due to highly prescriptive, supply-led interventions (Shaw and Conway, 2000).

Contemporary theorising has established that entrepreneurs learn much from each other (Johannisson, 2000; Pittaway and Rose, 2006), creating shared meaning through joint participation and interpersonal communication (Devins and Gold, 2002). The mutual understanding and empathy derived from shared experience can hopefully set the stage for constructive and generative dialogue and so "encourage the self-employed to articulate their feelings of grief, possibly speeding the recovery process" (Shepherd, 2003: 325). I see enormous value in bringing entrepreneurs together to actively talk about their loss and find common ground. In this open and supportive environment we can hopefully begin to remove some of the lingering taboos of failure (Cave et al., 2001), reduce feelings of isolation and despair and create more of a "mastery" reaction to failure (Cardon and McGrath, 1999).

Action learning approaches are increasingly being used as a crucial peer-to-peer entrepreneurial learning mechanism that facilitates collaborative critical reflection and reflexive action (Clarke et al., 2006; Florén and Tell, 2004). The therapeutic nature of action learning encapsulated as "comrades in adversity" (Revans, 1982) is certainly apt in relation to failure. In these facilitated "learning networks" the entrepreneur becomes part of a trustful and encouraging forum where reflection is given time and attention (Bessant and Tsekouras, 2001; Tell, 2000), potentially leading to "social, emotional and intellectual transformation" (McLaughlin and Thorpe, 1993:20). In the case of failure, this involves the opportunity to challenge articulated and tacit assumptions and, if appropriate, openly face a lack of knowledge and one's own level of culpability (Florén; 2003). It also enables entrepreneurs to learn vicariously from their peers, which remains a valuable form of learning from failure (Cannon and Edmondson, 2005; Coelho and McClure, 2005). Shepherd et al. (2008) maintain that "self-help support groups" can provide the emotional scaffolding needed to more effectively recover from grief, enabling entrepreneurs to learn coping skills and gain the confidence to face new challenges. 
Different compositions of action learning sets with distinctive objectives may be appropriate. In the case of entrepreneurs on the brink of failure, the aim can be to explore potential revisions to existing practices and consider any lucrative avoidance strategies. For entrepreneurs who have already experienced failure, the set can perform facilitated "after-event reviews" to collaboratively analyse the event and derive generative lessons that can improve future performance (Ellis et al., 2006). These action learning sets can be enhanced by more personalised mentoring, with entrepreneurs who have experienced failure perhaps mentoring those who are currently "looking into the abyss". This support mechanism has already been identified as pivotal in helping entrepreneurs overcome and learn from critical events (Cope and Watts, 2000; Sullivan, 2000).

\section{Conclusion}

The current global economic climate means that venture failure is a very real and threatening feature of entrepreneurial life. In seeking to understand the beneficial aspects of this experience I have sought to provide empirical weight to extant discussions of learning from failure, providing further conceptualisation of its process and content dimensions. I conclude that entrepreneurs who have experienced failure are arguably more prepared for the trials and tribulations of entrepreneurship than those who have only enjoyed success or prospective entrepreneurs who have yet to experience the often harsh realities and "pressure points" of the entrepreneurial process. The powerful and positive lessons derived from failure can give entrepreneurs revitalised confidence in their abilities and a broader, more sophisticated awareness and knowledge base. This is something that must be recognised and celebrated by policy-makers when devising programmes of support for entrepreneurial activity. Ultimately, I conclude that failure warrants a much more prominent position in discussions of entrepreneurship at academic, policy-maker and advisor levels.

Figure 1: The higher-level learning process associated with grief recovery 


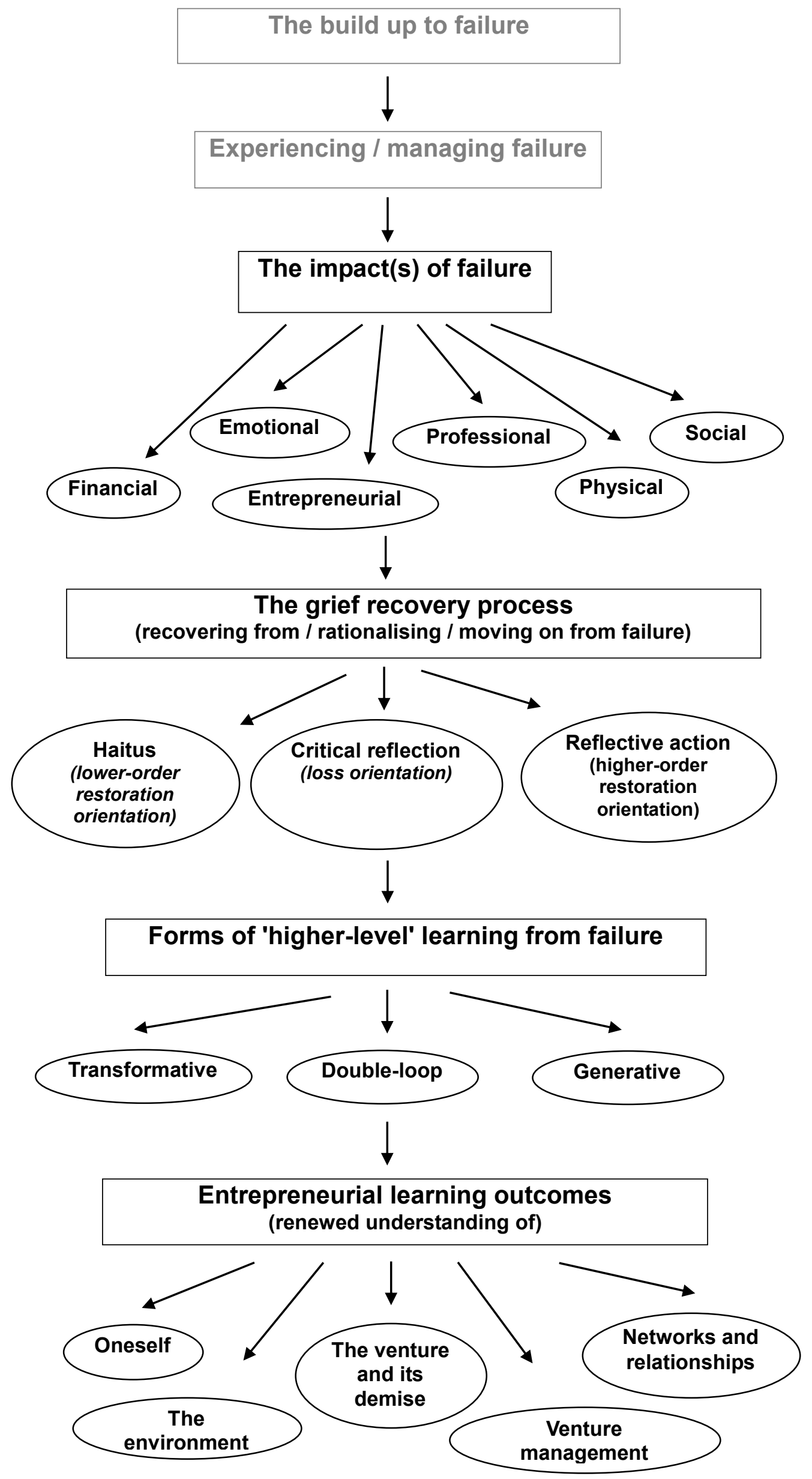

Figure 2: A learning framework for venture failure 
Ben (UK): Prior to purchasing his first and only company in 1987, Ben enjoyed a high profile managerial career in the manufacturing industry. In 1987 he raised four million pounds in venture capital and bank funding and purchased a joinery and woodworking company that made windows for new house builds, an industry that had been growing year on year. However, the UK recession began in 1988 and new house builds dropped between 35-40\%. As he recognises, he bought the company at a peak and it immediately went into a trough, making a profit in one month out of forty. With bankruptcy only a month away, in 1992 Ben decided to take control and called in the receivers. He has since returned to managerial roles in larger companies.

Colin (UK): After working on oil rigs as a communications officer, Colin purchased his first business in 1983, which was a training college for marine communications. He grew the company substantially and sold it in 1997. He purchased his second business, a lifestyle clothing store, in 2003. His aim was to develop a nation wide chain of stores and after securing $£ 400,000$ in venture capital funding began to open new stores with the aim of opening twelve stores. Although he successfully opening five stores, one very expensive city centre store did not trade well and was losing money rapidly. In 2006, he returned to his investors to refinance the expansion but they declined. At this point Colin realised that the company's debts could not be paid and decided to take the company into administration.

Gill (UK): Gill started her only company with a partner in the early 1980's, which involved training young women to work in promotion, including training programmes involving exercise, deportment and health and beauty. The business began to collapse when Gill's partner was suddenly taken into hospital after trying to commit suicide. Gill was left unable to deliver training programmes alone and incomes began to rapidly degenerate whilst the bank overdraft kept building. In 1987 Gill decided to avoid building further losses and dissolved the business. Gill was left with substantial personal debts that took over five years to pay off. She has never re-entered the entrepreneurial arena due to the emotional and financial strain that the failure created.

Nick (UK): Nick and his partner purchased his first business, a telecommunications company, in 1993. The market for mobile data was just emerging and the company had developed some innovate new software for mobile data transfer. However, the idea was ahead of its time, making inroads into the market proved very difficult, and development costs were higher than expected. Losses were mounting and so Nick decided to purchase the radio assets from the company to provide much needed capital, but the company could not be sustained and his partner decided to take the company into administration in 1996. Nick went on to develop the radio communications company, which became very successful and he later sold. He has since opened another telecommunications company.

George (US): After leaving university, George worked in, and started, a number of software and telecommunications companies in Silicon Valley. In 1998 he invested in starting a company which made telecommunications equipment for local exchange carriers. The company grew rapidly alongside these carriers and the company was on the verge of going public. In 2001, the market for exchange carriers began to collapse, orders fell through and suddenly losses began to mount. George tried to reposition the company to supply cable companies and unsuccessfully tried to secure additional funding to rebuild the company. In 2002, George decided to close the business to avoid further losses. He has since gone on to another executive position in a software start-up.

Hugh (US): Having occupied several executive positions in Silicon Valley start-ups, Hugh was part of an entrepreneurial team that started this software company in Silicon Valley in 1998. The company raised \$2 million in equity funding and was involved in developing systems for the rapid transfer of business data. The company was consumed with getting the product to market and developing a working prototype, but development schedules began to slip, the company changed product focus and the engineering team were having problems delivering what customers needed. The company was experiencing a $\$ 1$ million monthly burn rate. At this point, two of the founders left and Hugh struggled on for another year before deciding to close the company to avoid further losses. He is now working as a senior executive in another high-tech company in Silicon Valley.

Jake (US): Jake started his first software company in Silicon Valley in 1989 and sold it in 1995. He then started and sold a second software company and then went on to start his own investment fund. Having made 24 investments to date, this hightech company was his third investment. He was both an investor of $\$ 1$ million and founder. The company was involved in developing software that would make the internet more reliable in terms of transferring workload. Jake quickly realised that the product was ahead of its time and the market wasn't ready. The company also began to experience delays in product development. After unsuccessfully trying to sell the company's IP, in 2001 Jake closed the business to avoid further losses. He still operates his own investment fund and has made some very successful investments since this failure.

Tom (US): Tom started his first and only software company in Silicon Valley in 1988. After substantial growth and several rounds of funding from 3I, the company was floated in 1996. Despite 100\% year on year growth and several proposed acquisitions, in 1997 the company missed its expected quarterly target and shareholders began to sell their stock. This began to force the company's share price down, plummeting from \$26 per share to under a dollar by mid 1998. At this point, the board decided that enough was enough and Tom was exited. Six months later the company was liquidated and the assets were sold. Tom has since been involved in consultancy activities with other software companies in Silicon Valley. 


\begin{tabular}{ccc}
$\begin{array}{c}\text { Process } \\
\text { of analysis }\end{array}$ & $\begin{array}{c}\text { Level of } \\
\text { analysis }\end{array}$ & $\begin{array}{c}\text { Description of } \\
\text { analysis }\end{array}$ \\
\hline
\end{tabular}

Familiarisation / gaining insight case

Immersion and sense-making

Diagnosis of the case

Categorisation

Developing intra-case themes

$\begin{array}{ll}\text { Association/ } & \text { Developing } \\ \text { pattern } & \text { inter-case } \\ \text { recognition } & \text { themes }\end{array}$

Interpretation/ representation

Writing up $\begin{array}{ll}\text { Explanation and } & \text { Enfolding } \\ \text { abstraction } & \text { literature }\end{array}$
Reading and re-reading of the transcribed interview to gain an appreciation of the whole story and recall of the interview in both a cognitive and affective sense, thereby becoming 'intimate' with the account (Senior et al., 2002). Memos were captured as reflective notes on the issues identified (Patton, 1990).

During this process of immersion and sense-making, a 'free textual analysis' (Smith and Osborn, 2008) was performed, where potentially significant excerpts were highlighted. Building out from Hycner's (1985) technique, units of meaning were identified for each transcript. The units were then grouped to form common clusters of meaning. The clusters were colour coded throughout the transcript.

Linking the holistic reflective analysis (stage 1) with the clusters of meaning (stage 2) led to the emergence of themes that appeared to be salient to a particular interview in terms of learning from failure. This process of clustering units of relevant meaning (Hycner, 1985) led to a 'master-theme list' (Smith et al., 1999) for each transcript.

With stages 1-3 completed for all interviewees, a meta-level analysis across the cases was conducted. The eight master-theme lists were compared to identify and explain similarities and differences, thereby creating 'links' between accounts (Easterby-Smith et al., 2002). This involved looking for shared aspects of experience, creating superordinate categories that aggregated themes from across the accounts (Smith et al., 1999). This included both general and unique themes for all the interviews (Hycner, 1985).

This stage of analysis involved a formal process of writing up a 'narrative account of the interplay between the interpretative activity of the researcher and the participant's account of her experience in her own words' (Smith and Eatough, 2006; p338). Although the emphasis was on conveying shared experience, this process allows the unique nature of each participant's experience to re-emerge (Smith et al., 1999). To maintain an inductive, phenomenological approach to theory development, nascent theoretical propositions were written up from the data without the use of any relevant academic literature. This allowed the data to 'speak for itself' (Cope, 2005b).

During the analytical discussion of the data the theory-building process of 'enfolding literature' was conducted, which is required to produce a theoretical explanation at a higher level of abstraction (Eisenhardt, 1989). Hence, the research was phenomenologically grounded but also interpretative and hermeneutic (Berglund, 2007; Seymour, 2006). This involved an iterative and comparative process of tacking back and forth between existing theory and the data (Yanow, 2004), whilst remaining sensitive to the unique situated experiences of the participants.

Table 2: Levels of Interpretative Phenomenological Analysis 
Emotional

Financial

Physical

Social

Entrepreneurial 'I'm certainly not as blindly optimistic as I once was. I guess I never really thought about what could go wrong before and I've got to be careful now not to think about what could go wrong too much" (Tom).

"I am a bit more wary now" (Colin).

"I had to be bailed out in the end and that just knocked my self-confidence, it knocked everything...I think from that time I became less go for it" (Gill).

"I became a little pessimistic after that and certainly more cautious...I take relatively few risks and I suspect that probably another version of myself ten years ago would have been more expansionistic" (Nick).

Table 3: The costs of venture failure 


\section{Dimensions of the learning process}

'Haitus'

(leading to)

'Critical reflection'

(leading to)
Theoretical overview

Challenging forms of reflection that reexamine presuppositions and transform one's understanding of events and situations cannot occur immediately (Mezirow, 1991). Rather, learners need time to put problems into perspective and redefine them (Cope, 2005a).

Critical reflection is not concerned with the "how-to" of action, but rather the "why", examining the reasons for and consequences of what we do (Mezirow, 1991). In stimulating higher-level forms of learning, it requires that people "check out their assumptions...pay attention to surprising results and inquire into their meaning, ask probing questions, and reframe their understanding of what a problem may be" (Marsick and Watkins, 1990; 29).

Reflective action involves making decisions o taking other action predicated on the insights resulting from reflection (Mezirow, 1991). As Boud et al. (1985) assert, "while reflection is itself an experience, it is not, of course, an end in itself. It has the objective of making us ready for new experience' (1985: 34).
"Well it is something that you don't want to think too much about for the first year or two. It is only really after four or five years that I could think rationally about what I should have done, how I should have done it...It does affect you personally and it does take a while for the pain to diminish" (Ben).

"At the time...you are just heartbroken...Then a month goes by and you say 'what was I so upset about?' So at the time [it] looks like a mountain and as time goes by it becomes a molehill" (Jake).

"It was about six months really where I was spending most of the time in my now wife's apartment...I just learned tennis, went on the beach and read books and just...did almost nothing. I needed that, I needed just to heal and get over it, because it was very hurtful what happened" (Tom).

"I just really needed to sit back and evaluate what is it I want to do? How much of this really had my fingerprints on it and what could I have done differently?...But after a couple of months I kind of realised that every single day from the first to the last I did the best I could...I probably came to that realisation when the personal and professional relationships had all been repaired and we'd moved along, I'd got a different job and got back on more of a stable footing once this thing was in everybody's past' (Hugh).

"Did we make the right decisions? Did we pick the right strategy? Did we hire the right people? Did we make decisions in a timely manner? Did we treat our people fairly? You know, you go through all those sorts of things. I look at [company] and say in a sense we did. I did a better job on that one that the previous one that went public. So what was different? Well the times were different, the economies were different" (George).

"I kind of take issue with the whole thesis of the paralysing effects of failure... The fact is I lived through that and I saw a set of reasons why a company goes under and now I'm much more prepared to handle whatever the market sends to me...you've got to look at it and say 'ok, what is the lesson to be taken?"” (Jake).

“And when its happened, its happened, so what? I'd rather it hadn't happened, absolutely. If I had a chance to go back...I would undo several things but I don't have a chance to do that. It's a ticket to the bone yard for people that spend their time thinking about that. Its happened, get over it and you've got to move forward and find something else to do, otherwise give up, give everything up" (Colin).

"It's just one of those things that happens...you've got be mature about it and you've got to grow and...you've got to move on. It's not a career maker and it's not a career breaker...Is it the best part of my resume - no... but I also don't lose sleep over it, I don't think 'oh my God, my career has ended because I was part of a company that failed, I had my fingerprints on it"' (Hugh).

Table 4: The higher-order learning process associated with grief recovery 


\section{Learning task} dimension

\section{Oneself}

Learning about one's strengths, weaknesses, skills, attitudes, beliefs, areas for development.

\section{The venture (and its demise)}

Learning about the strengths and weaknesses of the venture, including reasons for the failure

\section{Higher-level learning process}

\section{'Transformative'}

Transformative learning has a deeply personal dimension, triggering profound changes in self-awareness and understanding (Mezirow, 1991), and entering into one's sense of identity (Boud et al., 1985). Often precipitated by a "disorienting dilemma" or crisis (Mezirow, 1990).
"I'm much more confident in myself and I'm very resilient I think now. I've been through so many difficult things and so many good things and bad things. I've got a much better sense of myself in terms of what I can do and what I can't, what I'm comfortable with, what I'm not comfortable with...I think my skills have broadened so much...I guess I was always on a steep learning curve, so it has just completely transformed my life from that point of view...I feel personally a much stronger person" (Tom).

"So the reason I'm a valuable CEO now is because of what I've been through. I've earned the right to make decisions because I've been in experiences where there's been a lot of money at stake. I've got my resiliency because I've seen what can happen, good and bad (Jake).

"I'm not afraid of small businesses, I'm not afraid of starting another company... in fact I'm stronger from the experience" (Hugh)

"I've never been the same since...I've never had the same total confidence as I had in those days, which has been good and bad" (Nick).

"I compare a company in trouble with the death of Julius Ceasar, it is not a very good analogy but it comes with a series of daggers, some bigger than others, some more deep than others, and in the end if the company is lucky over a period of time then it will recover. It may be impaired for ever but it will recover...There is no one fatal blow but cumulatively they will take effect. I think that is what happened to us" (Ben). understandings and assumptions of underlying organisational norms, processes and performance, leading to renewed mental models and revitalised theories-for-action (Argyris and Schön, 1978). These outcomes enable a deeper understanding of one's business (Cope, 2005a).
"I think we did it as smart as we could...it was a little ahead of its time. Other than that it wasn't a bunch of craziness going on...fundamentally it was not a bad experience because we lost money for the right reasons. We minimised everybody's [losses], we were very conservative with everything we spent, we didn't throw money around...I was very proud of what we did...It was good...for me to realise the lessons" (Jake).

"Its very easy to say now with hindsight but what I wouldn't probably do again is use the IPO as a mechanism for getting the value to sell it because the chances of success beyond that are actually very, very small, the number of companies that fail once you've done an IPO is actually quite high" (Tom)

"I thought I could take two businesses that weren't working and turn them into something that would work. I was totally wrong...I was effectively trying out an idea...that was out of time" (Nick) 


\section{Networks and relationships}

Learning about the nature and management of relationships, both internal and external to the venture

\section{Venture management}

Learning how to run and control businesses more effectively in relation to the wider environment

\section{'Transformative/double-loop}

"What I did learn is how to focus an organisation... and how not to do it as well. I learned how to build partnerships, I learned which kind of companies to seek out for partnerships, which is something most people have no idea of" (Tom).

"The fact of the matter is when a company goes bankrupt we lose money so it's a kick in the arse. But it may lead to something else, you may make a connection, you may make a friend, and so the idea is to keep it in perspective" (Jake).

"So your job is really getting everybody else marching down a path and you either get satisfaction from that or you don't. If you're frustrated by it you won't do it well. If you like it it means that you have to have a pretty thick skin" (George).

"So that's one thing I've learned, not to worry too much about what other people think" (Tom).

"I would never recommend a partnership" (Gill).

"I know a lot more about the things that you don't do. A lot more about the warning flags to see when the communications break down and all of us I think have learned how to handle intense daily pressure

better...how to work out what the warning signs are, how to communicate the warning signs so you can correct them before you go too far down the road is a very valuable lesson I think for all of us" (Hugh).

Involves the ability to extrapolate and "bring forward" one's learning from critical events to new situations, incidents and experiences (Gibb, 1997). Creates generalisable learning outcomes, allowing for more effective action in a broader range of new situations (McGill and Warner Weil, 1989).
"I think my big lesson was to concentrate on making sure you look after the daily bread. No matter how good your idea is...if you can't look after the here and now your idea is not enough...I'm always trying to contain costs and I'm much more aware of the stresses and strains of running a business than I was then" (Nick).

"I've got a model now of what you need to do and how you go about doing certain things...so I feel I can pretty much go into any area now" (Tom)

"Fundamentally the market has to be ready for what you want to do. You may be visionary and you may be ahead of your time but if the market is not ready for it, you're not ready. You can't change the market, the market is always right where it is supposed to be and it's your job as an entrepreneur to cater to the market" (Jake).

Table 5: Higher-level learning processes and outcomes associated with failure (adapted from Cope, 2005a). 


\section{References}

Aldrich, H.E. And Martinez, M.A. (2001), Many are called but few are chosen: An evolutionary perspective for the study of entrepreneurship, Entrepreneurship: Theory and Practice, 25(3), 41-56. Anderson, A.R., and Jack, S.L. (2002), The articulation of social capital in entrepreneurial networks: A glue or a lubricant? Entrepreneurship and Regional Development, 14(3), 193-210.

Anderson, A.R. And Miller, C.J. (2003), "Class matters": Human and social capital in the entrepreneurial process, Journal of Socio-economics, 32(1), 17-36.

Appelbaum, S. H., and Goransson, L. (1997), Transformational and adaptive learning within the learning organisation: A framework for research and application, The Learning Organisation, 4(3), 115-128.

Argyris, C., and Schön, D. A. (1978), Organisational Learning: A Theory of Action Perspective, Reading, MA: Addison-Wesley Publishing Co.

Baumard, P. and Starbuck, W.H. (2005), Learning from failures: Why it may not happen, Long Range Planning, 38(3), 281-298.

Beaver, G. (2003), Small business: Success and failure, Strategic Change, 12(3), 115-122.

Beaver, G. and Jennings, P.L. (1996), The abuse of entrepreneurial power-an explanation of management failure? Strategic Change, 5(3), 151-164.

Berglund, H. (2007), Researching entrepreneurship as lived experience, in Handbook of Qualitative Research Methods in Entrepreneurship, H. Neergaard and J.P. Ulhøi (Eds.), Cheltenham: Edward Elgar.

Bessant, J., and Tsekouras, G. (2001), Developing Learning networks, AI and Society, 15(1), 82-98.

Blackburn, R. and Kovalainen, (2008), Researching small firms and entrepreneurship: Past, present and future, International Journal of Management Reviews, 11(2), 127-148.

Bower, J.L. (1990), Business and battles: Lessons from Defeat, Harvard Business Review, JulyAugust, 48-53.

Boud, D., Cohen, R., and Walker, D. (1993), Introduction: Understanding learning from experience, in Using Experience for Learning, D. Boud, R. Cohen, and D. Walker, (Eds.), Buckingham: SRHE \& Open University Press.

Boud, D., Keogh, R. and Walker, D. (1985), What is reflection in learning? In D. Boud, R. Keogh and D. Walker, (Eds.), Reflection: Turning experience into learning, 7-17, London: Kogan Page.

Brocki, J.M. and Wearden, A.J. (2006), A critical evaluation of the use of interpretative phenomenological analysis (IPA) in health psychology, Psychology and Health, 21(1), 87-108.

Bryman, A.S. (2004), "Qualitative research on leadership: A critical but appreciative review", Leadership Quarterly, 15 (6), 729-769.

Burgoyne, J. (1995), Learning from experience: From individual discovery to meta-dialogue via the evolution of transitional myths, Personnel Review, 24(6), 61-72.

Cannon, D.R. (1995), Making sense of failure: Learning or defence, Unpublished Ph.D. Thesis, London Business School.

Cannon, M.D. And Edmondson, A.M. (2005), Failing to learn and learning to fail (intelligently): How great organizations put failure to work to innovate and improve, Long Range Planning, 38(3), 299-319.

Cannon, M.D. and Edmundson, A.M. (2001), Confronting failure: Antecedents and consequences of shared beliefs about failure in organizational work groups, Journal of Organizational Behavior, 22(2), 161-177.

Cardon, M. and McGrath, R.G. (1999), When the going gets tough...Toward a psychology of entrepreneurial failure and re-motivation, paper presented at the Frontiers of Entrepreneurship Research Conference, Babson College.

Cave, F., Eccles, S. and Rundle, M. (2001), "Attitudes towards entrepreneurial failure: A learning experience or an indelible stigma?" Proceedings of the 2001 Babson College-Kauffman Foundation Entrepreneurship Research Conference, Jonnkoping, Sweden, May.

Chapman, E. and Smith, J.A. (2002), Interpretative phenomenological analysis and the new 
genetics, Journal of Health Psychology, 7(2), 125-130.

Choo, C.W. (2008), Organizational disasters: Why they happen and how they can be prevented, Management Decision, 46(1), 32-45.

Clarke, J., Thorpe, R., Anderson, L. and Gold, J. (2006), It's all action, it's all learning: Action learning in SMEs, Journal of European Industrial Training, 30(6), 441-455.

Cochran, A.B. (1981), Small business mortality rates: A review of the literature, Journal of Small Business Management, 19(4), 50-59.

Coelho, P.R.P. and McClure, J.E., (2005), Learning from failure, Mid-American Journal of Business, 20(1), 13-20.

Cope, J. (2005a), Toward a dynamic learning perspective of entrepreneurship, Entrepreneurship: Theory and Practice, 29(4), 373-398.

Cope, J. (2005b), Researching entrepreneurship through phenomenological inquiry: Philosophical and methodological issues, International Small Business Journal, 23(2), 159-183.

Cope, J. (2003), Entrepreneurial learning and critical reflection: Discontinuous events as triggers for higher-level learning, Management Learning, 34(4), 429-450.

Cope, J., Cave, F. and Eccles, S. (2004), Attitudes of venture capital investors to entrepreneurs with previous business failure, Venture Capital: An International Journal of Entrepreneurial Finance, $6(2 / 3), 147-172$.

Cope, J. and Watts, G. (2000), Learning by doing: An exploration of experience, critical incidents and reflection in entrepreneurial learning, International Journal of Entrepreneurial Behaviour and Research, 6(3), 104-124.

Corbett, A.C. (2005), Experiential learning within the process of opportunity identification and exploitation, Entrepreneurship: Thoery and Practice, 29(4), 473-491.

Cressy, R. (2006), Why do most firms die young? Small Business Economics, 26(2), 103-116.

Deakins, D. (1996), Entrepreneurship and Small Firms, Maidenhead: McGraw-Hill.

Deakins, D., and Freel, M. (1998), Entrepreneurial learning and the growth process in SMEs, The Learning Organisation, 5(3), 144-155.

Denrell, J. (2003), Vicarious learning, undersampling of failure, and the myths of management, Organization Science, 14(3), 227-243.

Devins, D., Gold, J., Johnson, S., and Holden, R. (2006), A conceptual model of management learning in micro businesses: Implications for research and policy, Education and Training, 47(8/9), 540-551.

Devins, D. and Gold, J. (2002), Social constructionism: A theoretical framework to underpin support for the development of managers in SMEs? Journal of Small Business and Enterprise Development, 9(2), 111-119.

Down, S., (2006) Narratives of Enterprise: Crafting Entrepreneurial Identity in a Small Firm, Cheltenham: Edward Elgar.

Downing, S., (2005) The social construction of entrepreneurship: Narrative and dramatic processes in the coproduction of organizations and identities, Entrepreneurship: Theory and Practice, 29(2), 185-204.

Drakopoulou Dodd, S.D. (2002), Metaphors and meaning: A grounded cultural model of US entrepreneurship, Journal of Business Venturing, 17(5), 519-535

Drakopoulou Dodd, S., and Anderson, A.R., (2007) Mumpsimus and the mything of the individualistic entrepreneur, International Small Business Journal, 25(4), 341-360.

Eccles, S. A. (2000), Women and addictive consumption in the UK, unpublished Ph.D. thesis, The University of Lancaster.

Eisenhardt, K. M. (1989), Building theories from case study research, Academy of Management Review, 14(4), 532-550.

Ellis, S. and Davidi, I. (2005), After-event reviews: Drawing lessons from successful and failed experience, Journal of Applied Psychology, 90(5), 857-871.

Ellis, S., Mendel, R., and Nir, M. (2006), Learning from successful and failed experience: The moderating role of kind of after-event review, 91(3), 669-680. 
Fincham, R. (2002), Narratives of success and failure in systems development, British Journal of Management, 13, 1-14.

Fiol, C. M., and Lyles, M. A. (1985), Organisational Learning, Academy of Management Review, $10(4), 803-813$.

Florén, H. (2003), Collobarative approaches to management learning in small firms, The Journal of Workplace Learning, 15(5), 203-216.

Florén, H., and Tell, J. (2004), The emergent prerequisites of managerial learning in small firm networks, Leadership and Organization Development Journal, 25(3/4), 292-307.

Fox, S. (2000), Communities of practice, Foucault and actor network theory, Journal of Management Studies, 37(6), 853-868.

Fuller-Love, N. (2006), Management development in smaller firms, International Journal of Management Reviews, 8(3), 175-190.

Fredland, J. E. and Morris, C.E. (1976), A cross section analysis of small business failure, American Journal of Small Business, 1(1), 7-18.

Gaertner, K.N. (1988), Manager's careers and organizational change, Academy of Management Executive, 2(4), 311-318.

Gartner, W.B., and Birley, S. (2002), Introduction to the special issue on qualitative methods in entrepreneurship research, Journal of Business Venturing, 17(5), 387-395.

Gibb, A. A. (1997), Small firms" training and competitiveness: Building on the small business as a learning organisation, International Small Business Journal, 15(3), 13-29.

Gold, J., Holman, D. and Thorpe, R. (2002), The role of argument analysis and storytelling in facilitating critical thinking, Management Learning, 33(3), 371-388.

Gorman, M. and Sahlman, W.A. (1989), What doe venture capitalists do? Journal of Business Venturing, 4(4), 231-248.

Goss, D. (2005), Entrepreneurship and the social: Towards a deference-emotion theory, Human Relations, 58(5), 617-636.

Granott, N. (1998), We learn therefore we develop: Learning versus development - or developing learning? in Adult learning and development: Perspectives from Educational Psychology, M. Cecil Smith and T. Pourchot, (Eds.), Mahwah, NJ: Lawrence Erlbaum.

Greening, D.W., Barringer, B.R., and Macy, G. (1996), A qualitative study of managerial challenges facing small business geographic expansion, Journal of Business Venturing, 11(4), 223-256.

Gupta, A. (2005), Is failure so bad? Mid-American Journal of Business, 20(1), 3-4.

Hamilton, E. (2004), Socially situated entrepreneurial learning in family business, Proceedings of the $27^{\text {th }}$ National Small Firms Policy and Research Conference, Newcastle, November.

Harrison, R.T. and Leitch, C.M. (2005), Entrepreneurial learning: Researching the interface between learning and the entrepreneurial context, Entrepreneurship: Theory and Practice, 29(4), 351-372.

Hartley, J. F. (1994), Case studies in organisational research, in Qualitative Methods in Organisational Research, C. Cassell and G. Symon, (Eds.), London: Sage Publications.

Harvey, M., and Evans, R. (1995), Strategic windows in the entrepreneurial process, Journal of Business Venturing, 10, 331-347.

Headd, B. (2003), Redefining business success: distinguishing between closure and failure, Small Business Economics, 21(1), 51-61.

Hill, R.M. Hlavacek, J.D. (1977), Learning from failure: Ten guidelines for venture management, California Management Review, 19(4), 5-16.

Holman, D., Pavlica, K. and Thorpe, R. (1997) Rethinking Kolb's theory of experiential learning in management education, Management Learning, (28(2), 135-148.

Holmberg, S.R., and Morgan, K.B. (2003), Franchise turnover and failure: New research and perspectives, Journal of Business Venturing, 18(3), 403-418.

Hycner, R.H. (1985), "Some guidelines for the phenomenological analysis of interview data", Human Studies, 8, 279-303.

Jack, S. L. and Anderson, A. R. (2002), The effects of embeddedness on the entrepreneurial process, 
Journal of Business Venturing, 17(5), 467-487.

Jennings, P.L., and Beaver, G. (1995), The managerial dimension of small business failure, Journal of Strategic Change, 4(4), 185-200.

Johannisson, B. (2000), Networking and entrepreneurial growth, in D.L. Sexton and H. Lanström, (Eds.), The Blackwell Handbook of Entrepreneurship, Oxford: Wiley-Blackwell.

Jones, S. (1985), Depth Interviewing, in Applied Qualitative Research, R. Walker, (Ed.), Aldershot: Gower.

Kemmis, S. (1985), Action research and the politics of reflection, in Reflection: Turning Experience into Learning, D. Boud, R. Keogh, and D. Walker, (Eds.), London: Kogan Page.

Kim, D. H. (1993), The link between individual and organisational learning, Sloan Management Review, (Fall), 37-50.

Kisfalvi, V. (2002), The entrepreneur's character, life issues, and strategy making: A field study, Journal of Business Venturing, 17(5), 489-518.

Lincoln, Y. S., and Guba, E. G. (1985), Naturalistic Inquiry, London: Sage Publications.

Marshall, M.N. (1996), Sampling for qualitative research, Family practice, 13(6), 522-526.

Marsick, V.J. and Watkins, K.E. (1990), Informal and incidental learning in the workplace, London:

Routledge.

Mason, J. (2002), Qualitative Researching, London: Sage Publications.

McGill, I. and Beaty, L. (1995) Action Learning: A Guide for Professional, Management and Educational Development, Herndon, VA: Stylus Publishing.

McGrath, R.G. (1999), Falling forward: Real options reasoning and entrepreneurial failure, Academy of Management Review, 24(1), 13-30.

McKenzie, B. and Sud, M. (2008), A hermeneutical approach to understanding entrepreneurial failure" Academy of Entrepreneurship Journal, 14(2), 123-148.

McLaughlin, H., and Thorpe, R. (1993), Action Learning - A paradigm in emergence: The problems facing a challenge to the traditional management education and development, British Journal of Management, 4(1), 19-27.

Mellahi, K. (2005), The dynamics of boards of directors in failing organizations, Long Range Planning, 38(3), 261-279.

Mellahi, K. and Wilkinson, A. (2004), Organizational failure: A critique of recent research and a proposed integrative framework, International Journal of Management Reviews, 5-6(1), 21-41.

Mezirow, J. (1991), Transformative Dimensions of Adult Learning, San Francisco: Jossey-Bass.

Minniti, M. and Bygrave, W. (2001), A dynamic model of entrepreneurial learning, Entrepreneurship: Theory and Practice, 25(3), 5-16.

Morrison, A. (2000), Initiating Entrepreneurship, London: Pearson Education.

Mouly, V.S. And Sankaran, J.K. (2004), Survival and failure of small businesses arising through government privatization: Insights from two New Zealand firms, Journal of Management Studies, 41(8), 1435-1467.

Patton, M. Q. (1990), Qualitative Evaluation and Research Methods, London: Sage Publications.

Pittaway, L., and Cope, J. (2007), Simulating entrepreneurial learning: Integrating experiential and collaborative approaches to learning, Management Learning, 38(2), 211-233.

Pittaway, L., and Rose, M. (2006), Learning and relationships in small firms: Introduction to the special issue, International Small Business Journal, 24(3), 227-231.

Politis, D. (2008), Does prior start-up experience matter for entrepreneur's learning? A comparison between novice and habitual entrepreneurs, Journal of Small Business and Enterprise Development, 15(3), 472-489.

Politis, D. (2005), The process of entrepreneurial learning: A conceptual model, Entrepreneurship: Theory and Practice, 29(4), 399-424.

Politis, D. and Gabrielsson, J. (2009), Entrepreneurs' attitudes towards failure: An experiential learning approach, International Journal of Entrepreneurial Behaviour and Research, 5(4), 364383.

Rae, D. (2004), Entrepreneurial learning: a practical model from the creative industries, Education 
and Training, 46(8/9), 492-500.

Rae, D. (2000), Understanding entrepreneurial learning: A question of how?, International Journal of Entrepreneurial Behaviour and Research, 6(3), 145-159.

Ram, M., Theodorakopoulos, N., and Jones, T. (2008), Forms of capital, mixed embeddedness and Somali enterprise, Work, Employment and Society, 22(3), 427-446.

Ravasi, D. and Turati, C. (2005), Exploring entrepreneurial learning: A comparative study of technology development projects, Journal of Business Venturing, 20(1), 137-164.

Rerup, C. (2005), Learning from past experience: Footnotes on mindfulness and habitual entrepreneurship, Scandinavian Journal of Management, 21, 451-472.

Reuber, A. R., and Fischer, E. (1999), Understanding the consequences of founders' experience, Journal of Small Business Management, 37(2), 30-45.

Revans, R.W. (1982), The Origin and Growth of Action Learning, London: Chartwell Bratt.

Reynolds, M. (1998), Reflection and critical reflection in management learning, Management Learning, 29(2), 182-200.

Rogoff, E.G., Lee, M., and Suh, D. (2004), "Who done it?" Attributions of entrepreneurs and experts of the factors that cause and impede small business success, Journal of Small Business Management, 42(4), 364-376.

Sadler-Smith, E., Chaston, I., and Spicer, D.P. (1999), Organisational learning in smaller firms: An empirical perspective, Proceedings of the $3^{\text {rd }}$ International Organisational Learning Conference, M. Easterby-Smith, L. Araujo and J. Burgoyne, (Eds.), Department of Management Learning, Lancaster University.

Sarasvathy, S., and Menon, A. (2002), Failing firms and successful entrepreneurs: Serial entrepreneurship as a temporal portfolio, Darden Business School Working Paper No. 4-5.

Savitsky, K., Epley, N., and Gilovich, T. (2001), do others judge us as harshly as we think? Overestimating the impact of our failures, shortcomings and mishaps, Journal of Personality and Social Psychology, 81(1), 44-56.

Schutjens, V., and Stam, E. (2006), Starting anew: Entrepreneurial intentions and realizations subsequent to business closure, Max Planck Institute for Economics Entrepreneurship, Growth and Public Policy Discussion Paper No. 1006.

Scott, M. and Lewis, J. (1984), Re-thinking entrepreneurial failure, in Success and Failure in Small Business, J. Lewis, J. Stanworth and A. Gibb, (Eds.), Hampshire: Gower.

Senior, V., Smith, J.A., Michie, S. and Marteau, T.M. (2002), Making sense of risk: An interpretive phenomenological analysis of vulnerability to heart disease, Journal of Health Psychology, 7(2), 157-168.

Seymour, R.G. (2006) Hermeneutic phenomenology and international entrepreneurship research, Journal of International Entrepreneurship, 4(4), 137-155.

Shaw, E., and Conway, S. (2000), Networking and the small firm, in S. Carter and D. Jones-Evans, (Eds.), Enterprise and Small Business, Harlow: Financial Times/Prentice Hall.

Shepherd, D.A. (2009), Grief recovery from the loss of a family business: A multi- and meso-level study, Journal of Business Venturing, 24(1), 81-97.

Shepherd, D.A. (2004), Educating entrepreneurship students about emotion and learning from failure, Academy of Management Learning and Education, 3(3), 274-287.

Shepherd,D.A. (2003), Learning from business failure: Propositions of grief recovery for the selfemployed, Academy of Management Review, 28(2), 318-328.

Shepherd, D.A., Wiklund, J., and Haynie, M. (2009), Moving forward: Balancing the financial and emotional costs of business failure, Journal of Business Venturing, 24(2), 134-148.

Shepherd, D.A., Covin, J.G., and Kuratko, D.F. (2008), Project failure from corporate entrepreneurship: Managing the grief process, Journal of Business Venturing, in press.

Shepherd, D.A., Douglas, E.J. and Shanley, M. (2000), New venture survival: Ignorance, external shocks, and risk reduction strategies, Journal of Business Venturing, 15, 393-410.

Sheppard, J.P. And Chowdhury, S.D. (2005), Riding the wrong wave: Organizational failure as a failed turnaround, Long Range Planning, 38(3), 239-260. 
Singh, S., Corner, P. and Pavolvich, K. (2007), Coping with entrepreneurial failure, Journal of Management and Organization, 13(4), 331-344.

Sitkin, S.B. (1992), Learning through failure: The strategy of small losses. In B.M. Shaw \& L.L. Cummings (Eds.), Research in Organisational Behaviour, 14, 231-266.

Smith, J.A. (2004), Reflecting on the development of interpretative phenomenological analysis and its contribution to qualitative research in psychology, Qualitative Research in Psychology, 1, 39-54.

Smith, J.A., Jarman, M., and Osborn, M. (1999), Doing interpretative phenomenological analysis, in M. Murray and K. Chamberlain, (Eds.), Qualitative Health Psychology, London: Sage.

Smith, J.A. and Osborn, M. (2008), Interpretative phenomenological analysis, in Qualitative Psychology: A practical guide to research methods, $2^{\text {nd }}$ edition, J.A. Smith, (Ed.), London: Sage.

Smith, J.A. and Eatough, V. (2006), Interpretative phenomenological analysis, in Research Methods in Psychology, G.M. Breakwell, S. Hammond, C. Fife-Schan and J.A. Smith, (Eds.), London: Sage. Snell, R. (1992), Experiential learning at work: Why can't it be painless?, Personnel Review, 21(4), 12-26.

Stake, R. E. (1994), Case studies, in Handbook of Qualitative Research, N. K. Denzin and Y. S. Lincoln, (Eds.), London: Sage Publications.

Steyaert, C. (1997), A qualitative methodology for process studies of entrepreneurship, International Studies of Management and Organization, 27(3), 13-33.

Stokes, D. and Blackburn, R. (2002), Learning the hard way: The lessons of owner-managers who have closed their businesses, Journal of Small Business and Enterprise Development, 9(1), 17-27.

Sullivan, R. (2000), Entrepreneurial learning and mentoring, International Journal of Entrepreneurial Behaviour and Research, 6(3), 160-175.

Taylor, D. W. and Thorpe, R. (2004), Entrepreneurial Learning: A process of co-participation, Journal of Small Business and Enterprise Development, 11(2), 203-211.

Tell, J. (2000), Learning networks: A metaphor for inter-organizational development in SMEs, Enterprise and Innovation Management Studies, 1(3), 303-317.

Thompson, C. J., Locander, W. B., and Pollio, H. R. (1989), Putting consumer experience back into consumer research: The philosophy and method of existential phenomenology, Journal of Consumer Research, 16, 33-146.

Thornhill, S. and Amit, R. (2003), Learning about failure: Bankruptcy, firm age, and the resourcebased view, Organization Science, 14(5), 497-509.

Timmons, J.A. (1999), New Venture Creation: Entrepreneurship for the $21^{\text {st }}$ Century, Boston, MA: Irwin McGraw-Hill.

Venkataraman, S., Van De Ven, A.H., Buckeye, J., and Hudson, R. (1990), Starting up in a turbulent environment: A process model of failure among firms with a high customer dependence, Journal of Business Venturing, 5(5), 277-295.

West, G. P., and Wilson, E. V. (1995), A simulation of strategic decision making in situational stereotype conditions for entrepreneurial companies, Simulation and Gaming, 26(3), 307-327.

Whyley, C. (1998), Risky Business, Westminster: Policy Studies Institute.

Wilkinson, A. and Mellahi, K. (2005), Organizational failure: Introduction to the special issue, Long Range Planning, 38(3), 233-238.

Willmott, H. (1997), Critical management learning, in Management Learning: Integrating perspectives in theory and practice, J. Burgoyne and M. Reynolds, (Eds.), London: Sage Publications.

Yanow, D. (2004), Translating local knowledge at organizational peripheries, British Journal of Management, 15(1), 9-25.

Zafirovski, M. (1999), Probing into the social layers of entrepreneurship: Outlines of the sociology of enterprise, Entrepreneurship \& Regional Development, 11(4), 351 - 371.

Zacharakis, A.L., Meyer, G. and DeCastro, J. (1999), Differing perceptions of new venture failure: A matched exploratory study of venture capitalists and entrepreneurs, Journal of Small Business Management, 37(3), 1-14. 
Zahra, S.A. (2007), Contextualizing theory building in entrepreneurship research, Journal of Business Venturing, 22(3), 443-452. 